\title{
Factors Influencing Attachment toward Fukushima-gata Lagoon: Analyzing Changes in the Lifestyle of Regional Residents
}

\author{
Daiki Ogawa ${ }^{1}$ and Rui Fukumoto ${ }^{2, *}$ \\ 1 Design Course, Department of Design, Nagaoka Institute of Design Graduate School, 4-197, Senshu, \\ Nagaoka-shi, Niigata-ken 940-2088, Japan; a175002@st.nagaoka-id.ac.jp \\ 2 Department of Architecture and Environmental Design, Nagaoka Institute of Design, 4-197, Senshu, \\ Nagaoka-shi, Niigata-ken 940-2088, Japan \\ * Correspondence: rfukumoto@nagaoka-id.ac.jp; Tel.: +81-258-21-3539
}

Received: 29 January 2019; Accepted: 9 June 2019; Published: 17 June 2019

\begin{abstract}
The growing shortage of human resources for managing landscape in the water environment has led to problems concerning the preservation of the landscape in Japan. For developing people have the awareness to preserve the landscape, it is important to understand the process of how regional residents develop attachment toward the water environment in their area. This paper identified factors influencing the frequency of the visits to the water environment and the attachment of residents toward the Fukushima-gata lagoon, Niigata Prefecture, Japan, as a case study, while focusing on changes in the lifestyle of the regional residents. The findings are as follows: (1) The target households frequently used Fukushima-gata lagoon for fishing and for picking edible wild plants and gathering reeds to make thatched roofs before the reclamation project was carried out by the government in Fukushima-gata lagoon. They also frequented Fukushima-gata lagoon for walking and cherry blossom viewing after the reclamation project was implemented. (2) Even the fact that the distance from the lagoon to their place of residence increased after the project did not lose their attachment to the lagoon. (3) It was suggested that the project contributed to increase the attachment of regional residents towards Fukushima-gata lagoon because of multiple factors, such as playing in the water, livelihood opportunities, and recreational use. (4) Changes in the attachment of regional residents toward Fukushima-gata lagoon before and after the reclamation project was carried out by the government corresponded to changes in the lifestyle of the local residents before and after the project.
\end{abstract}

Keywords: Fukushima-gata lagoon; attachment; changes in lifestyle; actual condition of use

\section{Introduction}

\subsection{Research Background}

The growing shortage of human resources for managing landscapes in a water environment in Japan-where there is a declining birthrate and aging population — has led to problems concerning the preservation of the landscape. To cultivate an awareness about preserving the landscape, it is important to understand the process through which regional residents become attached to the water environment. Previous studies have reported on the factors that led residents to develop an attachment (in this paper, "frequency of visits the water environment" was set to "degree of attachment") toward their water environment. Multiple factors, such as the distance between the home and the target area [1] and the number of years of residence in the area [2], have been mentioned. However, these are based on research results evaluated at a specific point in time, and corresponding changes in regional 
residents' lifestyle have not been examined, and therefore, integrated research referring to changes in attachment and the formation factors of attachment is lacking [3].

\subsection{The Government Reclamation Project for the Fukushima-gata Lagoon}

The Fukushima-gata lagoon in Japan meets the conditions to make it a suitable target site. The government reclamation project for Fukushima-gata lagoon [4] (hereinafter referred to as the reclamation project) was conducted in the 1960s, leading to an increase in the distance between the settlement adjacent to the water area subject to reclamation and the visible outline of the Fukushima-gata lagoon. The reclamation project was conducted from 1968 to 1975, for the purpose of increasing rice crop production. At the beginning of the project planning, the full reclamation of Fukushima-gata was planned, but the flood control function of Fukushima-gata was recognized when the 7.17 Shimoetsu Flood Damage occurred in 1966 and 8.28 Uetsu Flood Damage occurred in 1967, the following year. For that reason, Fukushima-gata became an agricultural land after 169 ha of the area (362 ha) before national reclamation was reclaimed. Fukushima-gata lagoon had an area of 262 ha in 2018 [4] (Figure 1). Fukushima-gata lagoon lies in the alluvial plain [5], and the altitude of the surrounding area is $0 \mathrm{~m}$ to $5 \mathrm{~m}[6]$.

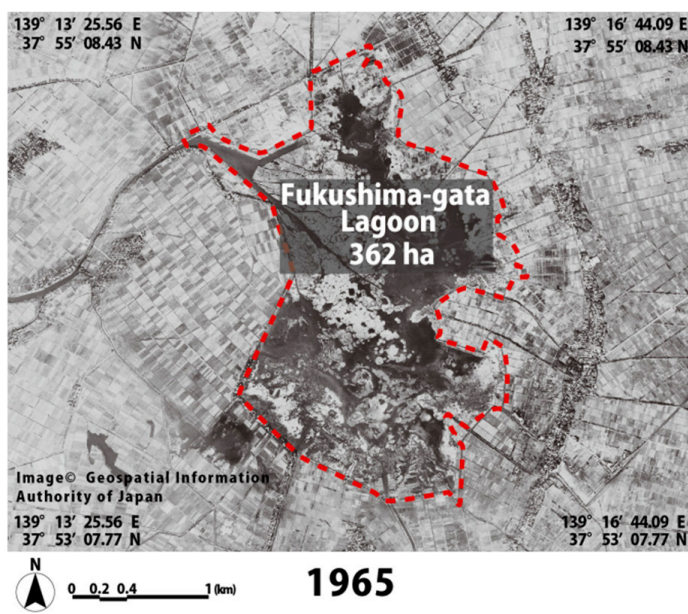

(a)

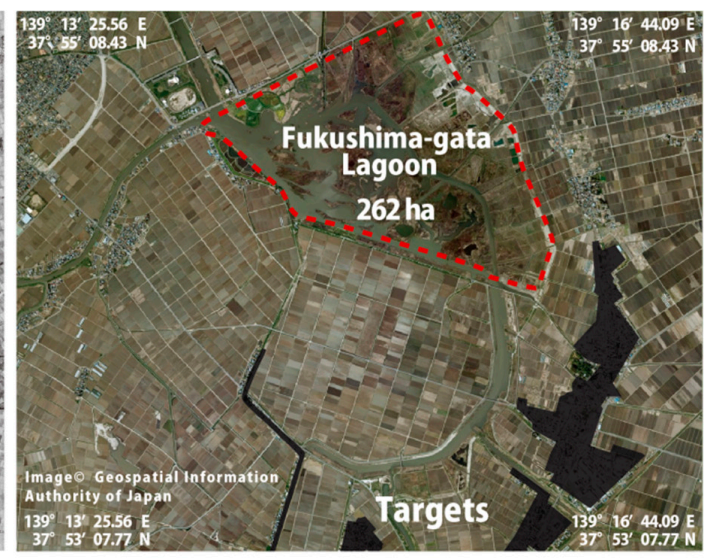

2018

(b)

Figure 1. Study area. (a): Fukushima-gata lagoon before the reclamation project (1965) [6]; (b): Fukushima-gata lagoon after the reclamation project (2018) [6]. Red dotted line: outline of the Fukushima-gata lagoon. The target village (black filled range) made expressions that do not specify villages from ethical consideration.

In some previous studies, the focus of the research was on how distances or time of travel changed individually for the local residents from their residence to the water environment, depending on the changes in their lifestyle, which included regional residents' moving. On the other hand, in the case of the Fukushima-gata lagoon, as the area of the Fukushima-gata lagoon decreased due to the reclamation project and its visible outline changed, and being a region where changes in distance and required time (which were previously reported as variables with a large influence) occurred for all target settlements, it was able to handle these as invariables in this research. Therefore, it became easier to consider the influence of other factors responsible for a change in their living arrangements. In addition, the lifestyles of regional residents living in a settlement around the Fukushima-gata lagoon changed dramatically. Therefore, the target area was considered to be an area suitable for examining factors influencing attachment based on changes in lifestyle. 


\subsection{Research Objectives}

Settlements around Fukushima-gata lagoon where the lifestyle of regional residents had changed were selected for this study. This paper aimed to understand the level of attachment of local residents toward the Fukushima-gata lagoon and how these residents used (Note 1) the lagoon before and after the reclamation project, based on the theoretical framework. Besides this, another aim was to understand the corresponding relationship between the changes in attachment and changes in lifestyle as factors influencing their attachment toward the lagoon.

\section{Literature Review}

In this section, the theoretical framework for achieving the purpose of this research is set, based on previous studies.

\subsection{Previous Studies}

Previous studies related to this study were classified into four categories: (1) research related to preserving water environments; (2) research related to the formation of an attachment toward the water environment and places; (3) research related to promoting the use of water environments; and (4) research related to the Fukushima-gata lagoon.

(1) Regarding preserving water environments

Regarding hygrophyte diversity, the use of grazing water buffalo as a form of management may reduce reeds and increase other hygrophytes, thus harmonizing the benefits of landscape and bird conservation [7]. Large (at least $800 \mathrm{~m}^{2}$ over) plots of constructed wetlands in abandoned fields remove nutrients from agricultural wastewater [8]. These studies reported findings related to preserving the diversity of landscapes and hygrophytes. Besides this, there are many studies related to innovative approaches and the investigation of coastal lagoons and wetlands. For example, GIS (Geographical Information System) participatory analysis [9], hydro-economic analysis [10], social valuation [11], and vulnerability and risk assessment [12].

(2) Regarding the formation of attachment toward the water environment and places

Studies related to the formation of an attachment towards the water environment and the area reported various influencing factors, including age $[13,14]$, number of years of residence [2,14-19], distance and travel time [1,20], visit frequency $[16,21,22]$, participation in the regional community [23-26], initiatives for preservation [21,22,27-29], recreational use [30-32], and livelihood use [33,34]. Those factors related to lifestyle describe the formation of attachment. However, these results present the actual lifestyle situation at a certain point in time; the changes in lifestyle that form the research objectives in this study have not been examined. Therefore, the studies examining changes in attachment and the form factors of the attachment corresponding to changes in the lifestyles of regional residents are insufficient.

(3) Regarding promoting the use of water environments

Studies related to promoting the use of water environments found a positive correlation between the attachment of the local residents to the landscape and the support of the conservation plan, and the residents' negative recognition of the changing of the landscape was a supportive action from the residents for the new positive planning [35]. Place attachment leads to the motivation of the local residents' activity [36,37]. Attachment to nature is a predictor of environmental protection behavior [38]. However, most of the previous studies focused on the factors which form attachment in the short-term, and did not identify the factors which form attachment in the long-term. 
(4) Regarding the Fukushima-gata lagoon

Studies related to the Fukushima-gata lagoon reported on vegetation surveys [39], subsurface exploration [40], ecological surveys of wild birds [41], flood control plans [42], and natural environment plans [43]. In addition, the Niigata City Lagoon Environment Research Institute for Environmental Studies (Note 2) has published various investigative reports on the Fukushima-gata lagoon [44,45]. Therefore, a survey on how regional residents use resources of the lagoon does not exist.

For the purposes of this study, we will use the term "attachment" to advance discussion. The term "place attachment" is often used in terms of attachment to specific places, such as water environments and regions $[13,15,16]$. In previous studies, place attachment had two common definitions: (1) positive emotions an individual holds regarding a specific place, and (2) an active relationship between an individual and a specific place. Because the focus in this study is on the Fukushima-gata lagoon and the regional residents around it, the definition of "attachment" can be stated as follows: (1) positive emotions that regional residents hold toward the Fukushima-gata lagoon, or (2) the relationship between regional residents and Fukushima-gata lagoon, formed by positive emotions regional residents have towards the Fukushima-gata lagoon. Next, although the term attachment is not used, "regional identity" is cited as a similar concept, and there are many studies based on this concept [1,3,46-48]. In previous studies, "regional identity" has had three common definitions: (1) the attachments a resident forms in a certain region, (2) a sense of belonging towards a region, known as attachment, and (3) the common aspects shared in a regional community. Attachment is a positive emotion toward the target area, whereas regional identity includes not only attachment toward the target area but also a sense of belonging in the target area. Therefore, even though regional residents do not have a positive emotion toward the target area, examples are recognized where landscapes specific to a region are recognized as regional identity [32]. To cultivate persons who are conscious about preserving the landscape, it is important to understand the process through which regional residents form attachments to their water environment.

\subsection{Theoretical Framework}

Based on the findings of previous studies, the theoretical framework for achieving the purpose of this paper was set, as shown in Figure 2.

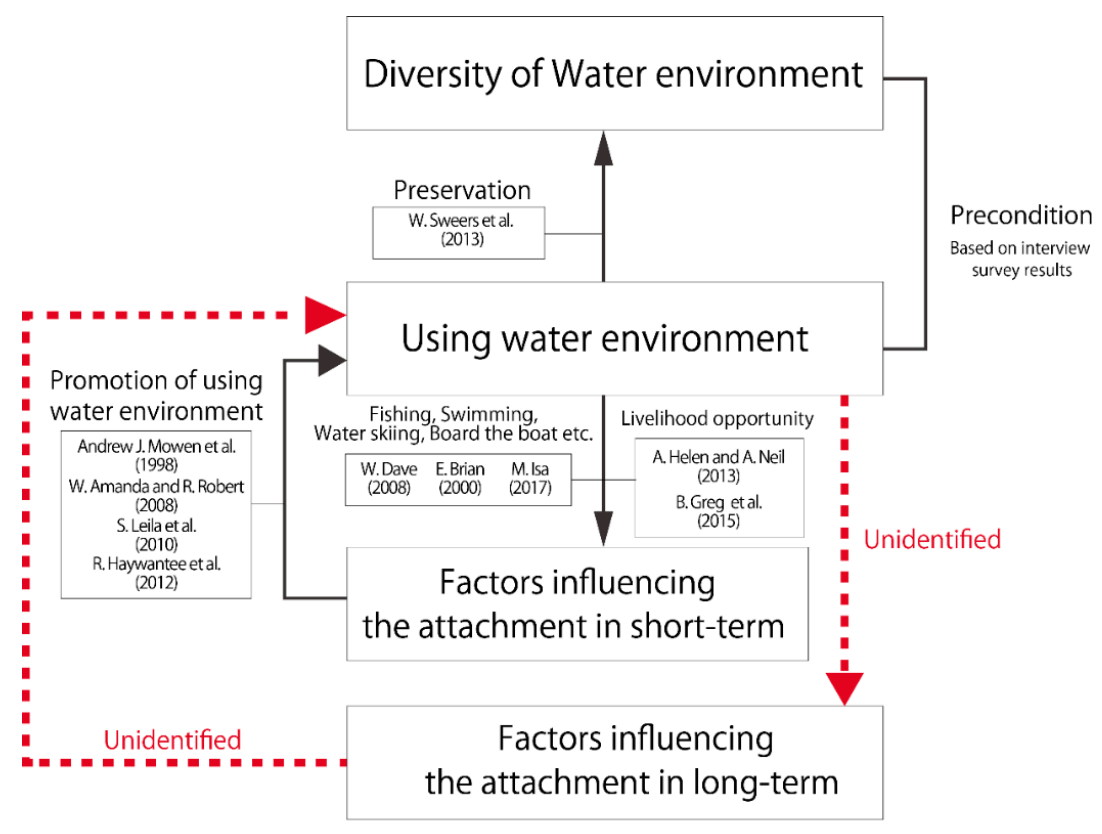

Figure 2. Theoretical framework. 
Various factors were identified which form attachment in the short-term. However, the factors which form attachment in the long-term were not identified. In addition, not only the impression on the water environment, but also empirical indicators contributing to the maintenance and management of the water environment, such as the frequency of visiting the water environment, identify the factors that form attachment in the long term on the utilization of the water environment. It is thought that this leads to promotion and contributes to the sustainability of the conservation of the water environment.

\section{Research Design and Method}

This study consists of three parts: case study, data collection analysis, and discussion. First, in the case study, through interviews with local residents and geospatial analysis of the target area, hypotheses that contribute to the formation of long-term attachment were derived and the question items for examining those hypotheses were determined. Second, the data collection and analysis department carried out a questionnaire survey to test hypotheses for all households in the target village and carried out analysis by simple tabulation, cross-tabulation, and correlation analysis. Third, in the discussion section, we considered the attachment facing the Fukushima-gata lagoon before and after the reclamation project and used the situation of the Fukushima-gata lagoon and factors influencing attachment towards the Fukushima-gata lagoon, performed hypothesis validation, and mentioned the limitations.

\subsection{Case Study}

To formulate hypotheses and clarify variables, we first conducted an interview survey of local residents who were familiar with the Fukushima-gata lagoon before the reclamation project. We obtained the participants' consent to publish the data for academic purposes on the condition of maintaining the anonymity of the interviewee.

\subsubsection{Interview Survey}

The interview survey was conducted for three regional residents around the Fukushima-gata lagoon, Mr. A, Mr. B, and Mr. C, from among the residents engaged in the preservation activities of the Fukushima-gata lagoon and residents holding posts in the neighborhood association (Table 1). The three respondents interviewed for this survey were born and raised in the area around the Fukushima-gata lagoon, and they frequently used the Fukushima-gata lagoon both before and after the reclamation project, hence, it is assumed that all three have an attachment toward the Fukushima-gata lagoon.

Table 1. Outline of the interview survey.

\begin{tabular}{|c|c|c|}
\hline \multirow{2}{*}{ Interviewees } & \multicolumn{2}{|c|}{ Regional residents around Fukushima-gata lagoon } \\
\hline & Mr. A, Mr. B & Mr. C \\
\hline \multirow{2}{*}{ Survey Dates } & 24 June 2017 & 16 July 2018 \\
\hline & 30 June 2018 & 31 July 2018 \\
\hline Implementation Method & \multicolumn{2}{|c|}{ Direct interview } \\
\hline Question Item & \multicolumn{2}{|c|}{$\begin{array}{l}\text { (1) The attributes of the target person } \\
\text { (2) Changes in Fukushima-gata lagoon before and after the reclamation } \\
\text { project } \\
\text { (3) The use of Fukushima-gata lagoon before and after the reclamation } \\
\text { project }\end{array}$} \\
\hline
\end{tabular}

Our interviews with both Mr. A and Mr. B were held on 24 June 2017 and 30 June 2018, and with Mr. C on 16 July 2018, and 31 July 2018. Our interview survey lasted two to three hours per interview and was carried out twice.

Using a semi-structured interview format, we asked respondents about (1) attribute information, (2) changes in the Fukushima-gata lagoon before and after the reclamation project, and (3) the actual 
condition of use of the Fukushima-gata lagoon by the respondents before and after the reclamation project (Table 2).

Table 2. Results of the interview survey.

\begin{tabular}{|c|c|c|c|}
\hline Targets & Mr. A & Mr. B & Mr. C \\
\hline Occupation & Farmer & Private Enterprises & Private Enterprises \\
\hline Post & $\begin{array}{l}\text { Environment } \\
\text { preservation volunteer }\end{array}$ & $\begin{array}{l}\text { Environment } \\
\text { preservation volunteer }\end{array}$ & $\begin{array}{l}\text { Neighborhood } \\
\text { association officer }\end{array}$ \\
\hline Residence years & 60-70 years & 60-70 years & 60-70 years \\
\hline $\begin{array}{l}\text { Changes in } \\
\text { Fukushima-gata lagoon }\end{array}$ & $\begin{array}{l}\text { - Plants have decreased } \\
\text { - Landscape got worse } \\
\text { - Fish and birds cease to } \\
\text { be caught } \\
\text { - Flood measures were } \\
\text { implemented } \\
\text { - It became difficult to } \\
\text { earn income at the } \\
\text { Fukushima-gata lagoon }\end{array}$ & $\begin{array}{l}\text { - Vegetation has changed } \\
\text { - Number of fish has } \\
\text { decreased } \\
\text { - Area diminished, the } \\
\text { scenery changed } \\
\text { - Fukushima-gata lagoon } \\
\text { is no longer a place of life }\end{array}$ & $\begin{array}{l}\text { - Landscape has changed } \\
\text { - Water got dirty and } \\
\text { fish decreased } \\
\text { - Embankment increased } \\
\text { due to flood control } \\
\text { - Road was improved } \\
\text { along the embankment } \\
\text { - Many tourists came } \\
\text { from the downtown to } \\
\text { see the cherry blossoms } \\
\text { - Number of tourists } \\
\text { increased and the } \\
\text { amount of garbage } \\
\text { increased }\end{array}$ \\
\hline $\begin{array}{l}\text { Actual condition of use } \\
\text { of Fukushima-gata } \\
\text { lagoon }\end{array}$ & $\begin{array}{l}\text { - In the past I sold fish } \\
\text { and birds I picked up but } \\
\text { now I cannot sell } \\
\text { - I picked Wild rice and } \\
\text { sold it, but I have no } \\
\text { taken it since Wild rice } \\
\text { has decreas } \\
\text { - I was fishing on my } \\
\text { own ship } \\
\text { - When I was a child I } \\
\text { played swimming } \\
\text { - Compared with the } \\
\text { past, fish did not sel but } \\
\text { it is still frequently on } \\
\text { board the boat }\end{array}$ & $\begin{array}{l}\text { - I used to live in fishery, } \\
\text { but now it is difficult to } \\
\text { earn income } \\
\text { - In the past I took a } \\
\text { sparrow and ate it but } \\
\text { now I cannot catch it } \\
\text { - When I was a child, I } \\
\text { took a boat and } \\
\text { competed with my } \\
\text { friends } \\
\text { - Before national } \\
\text { reclamation I was } \\
\text { swimming in the estuary } \\
\text { and playing } \\
\text { - I used to ride a boat to } \\
\text { fish in the past but now it } \\
\text { is only riding at the event }\end{array}$ & $\begin{array}{l}\text { - I used to mow yoshi } \\
\text { and sold it in old days } \\
\text { - My parents used the } \\
\text { lagoon water for } \\
\text { agricultural water } \\
\text { - In the spring we will } \\
\text { see the cherry blossoms } \\
\text { in the south of } \\
\text { Fukushima-gata lagoon } \\
\text { - I picked lotus fruit and } \\
\text { fish, sold it and living } \\
\text { - I often walk around } \\
\text { Fukushima lagoon and } \\
\text { look back at old } \\
\text { Fukushima-gata lagoon }\end{array}$ \\
\hline
\end{tabular}

Attribute Information of the Respondents Interviewed

Regarding the occupation of the respondents interviewed, Mr. A was a farmer, Mr. B and Mr. C were working for a private enterprise. At the time of the interview survey, Mr. A and Mr. B had retired, and $\mathrm{Mr}$. $\mathrm{C}$ was an incumbent. The role of the respondents interviewed refers to their role in the target area. Mr. A and Mr. B were engaged in the preservation activities of the Fukushima-gata lagoon and Mr. C served a post at the neighborhood association where he lives. Common among the responses of the respondents interviewed were "I have participated in the preservation in the Fukushima-gata lagoon and the planning of events" and "I have lived around the Fukushima-gata lagoon area for over 60 years, since I was a child".

Changes in the Fukushima-gata Lagoon before and after the Reclamation Project

The common response to changes in the Fukushima-gata lagoon before and after the reclamation project was as follows: "residents reclaimed plants and fish, and the landscape of the Fukushima-gata 
lagoon changed". In addition, Mr. A and Mr. B testified that "the Fukushima-gata lagoon before the reclamation project was a place for daily living" and "we sold fish and plants to earn income".

Actual Condition of Use of the Fukushima-gata Lagoon before and after Reclamation Project by the Interviewed Respondents.

Among the responses obtained about the actual condition of use by the interviewed respondents of the Fukushima-gata lagoon before and after the reclamation project, many were related to daily life, such as getting on a boat for "fishing, picking edible wild plants, gathering reeds for the thatched roof".

It was possible to get a harvest by riding in a boat. There was a difference in the three respondents' responses regarding the use of the Fukushima-gata lagoon after the reclamation project. Mr. A frequently used to use boats even after the reclamation project, but no longer for fishing or picking edible wild plants. Mr. B used to take boats only for guiding tourists to the Fukushima-gata lagoon after the reclamation project. Mr. C did not use boats after the reclamation project and answered, "I only go to the Fukushima-gata lagoon for walking and for the scenic view". Before the reclamation project, their relationship with the Fukushima-gata lagoon was as a means of living, common to the three respondents, but after the reclamation project, changes in the individual lifestyles of the local residents influenced them to make different use of the Fukushima-gata lagoon.

\subsubsection{Geospatial Analysis}

Figure 3 shows the situation of land use in the target area as of 1965 and 2018. The changes in land use ratio between 1965 and 2018 are as follows: paddy fields decreased from $83.7 \%$ to $78.2 \%$, farmlands increased from $0.4 \%$ to $1.3 \%$, river and wetland areas decreased from $6.9 \%$ to $5.0 \%$, residential areas increased from $5.0 \%$ to $11.3 \%$, forests decreased from $3.9 \%$ to $2.7 \%$, public facilities increased from $0 \%$ to $0.4 \%$, and golf courses increased from $0 \%$ to $1.1 \%$.

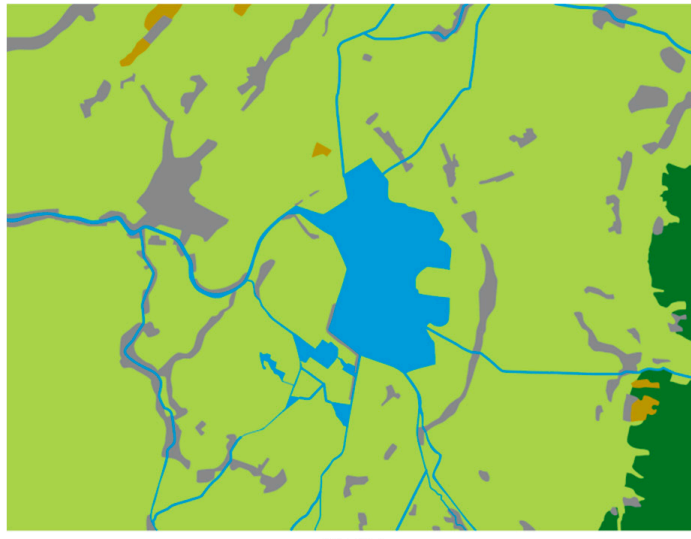

1965

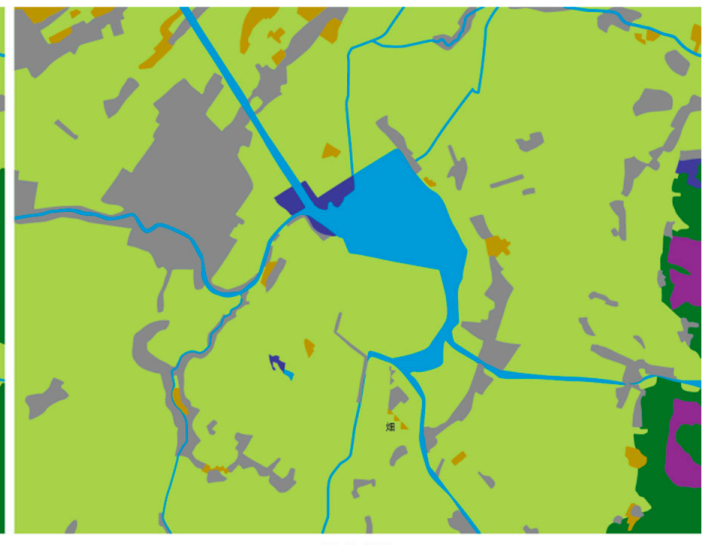

2018

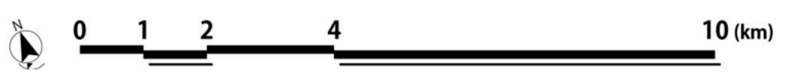

Figure 3. Land use around the Fukushima-gata lagoon. Based on the National Land Numeral Information Land Use Subdivision $100 \mathrm{~m}$ Mesh Data (2014) [6], clear figures were prepared using QGIS (Quantum GIS) 2.18.2.

Figure 4 shows a cross-sectional view including the water depth of Fukushima Lagoon investigated by the authors in August 2018 and its locations. There were many abandoned farmland areas near the residential area, however, based on this investigation there were many wetlands with various water depths inside the Fukushima-gata lagoon. 


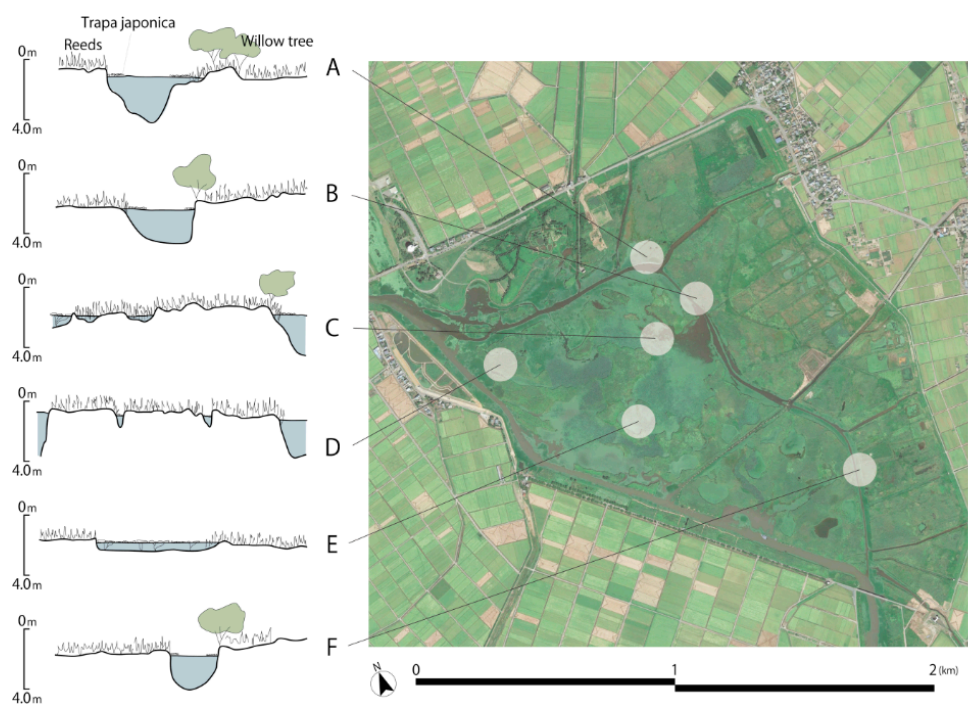

Figure 4. Diversity of water depth in the Fukushima-gata lagoon.

\subsubsection{Formulating Hypotheses}

From the results of the interview survey, it was suggested that the usage of the Fukushima-gata lagoon was different before and after the reclamation project. From the above, it was thought that before the reclamation project, uses were related to eating (catching fish and plants) and housing (getting reeds for building materials), but after the reclamation project the uses related to eating and housing were greatly reduced. As a hypothesis based on the above, we assumed Hypothesis 1-the Fukushima-gata lagoon after the reclamation project has a largely diminished use related to eating (catching fish and plants) and housing (getting reeds for building materials), and it is rarely used by regional residents.

Previous studies have mentioned that various factors influence the formation of short-term attachment to the target site [1,2,13-34]. However, long-term attachment has not been considered. As a hypothesis based on the above, let us assume Hypothesis 2-not only the use of the water environment after the reclamation project but also the use of the water environment before the reclamation project affect the formation of long-term attachment.

In addition, due to differences in the use of the Fukushima-gata lagoon after the reclamation project by the subjects of the interview survey, we classified the use of the Fukushima-gata lagoon as "playing in the water", "livelihood opportunity", and "recreational use". As a hypothesis based on the above, we assumed Hypothesis 3-the factors of playing in the water, livelihood opportunities, and recreational use are involved in forming long-term attachments towards the Fukushima-gata lagoon.

\subsection{Targets}

The targets were the settlements shown in Figure 1 ( 37 households in total). The criterion for selection of the targets was that it was assumed that residents' use of the lagoon greatly changed before and after the reclamation project because the distance from their settlement to the waterfront of the Fukushima-gata lagoon $(\max 2.25 \mathrm{~km})$ greatly changed after the reclamation project.

\subsection{Questionnaire Survey}

In order to clarify the corresponding relationship between the Fukushima-gata lagoon use conditions before and after the reclamation project and the degree of attachment toward the Fukushima-gata lagoon, we visited all households ( 37 households) of the settlement with the cooperation of the neighborhood association and distributed and collected a questionnaire (response rate 83.7\%). The outline of the questionnaire survey was as shown in Table 3, and the question contents were as shown in Table 4 . In addition to the basic attributes of the respondents, the question items were about 
the impression evaluation and use of the Fukushima-gata lagoon before and after the reclamation project and their grasp of the actual condition.

Table 3. Outline of the questionnaire survey.

\begin{tabular}{|c|c|}
\hline Date of Implementation & August 2018 \\
\hline Target & All households of target village (37 households) \\
\hline Implementation Method & Self-written questionnaire survey \\
\hline Answer Method & Selection formula/Free description formula \\
\hline Distribution/Collection Method & Distribution/collection by visit \\
\hline Number Collected & 31 households (Response rate $83.7 \%$ ) \\
\hline \multicolumn{2}{|c|}{ Questionnaire Survey Question Contents } \\
\hline $\begin{array}{l}\text { 1. Respondent attribute (Gender/Age/Profes } \\
\text { 2. The frequency of visiting Fukushima-gatc } \\
\text { 3. Events and gatherings held in the area an } \\
\text { 4. Impression evaluation (change in attachn } \\
\text { lagoon } \\
\text { 5. Usage situation before and after the recla } \\
\text { (Play in the water), (Boarding the boat), (Fish } \\
\text { material), (Walking), (Photography), (Viewin } \\
\text { etc. All } 26 \text { items }\end{array}$ & $\begin{array}{l}\text { tructure/Residence years) } \\
\text { ipation status } \\
\text { nd after the reclamation project for Fukushima-gata } \\
\text { t of Fukushima-gata lagoon } \\
\text { na wild birds), (Catching fish), (Sell reeds as building } \\
\text { na-gata lagoon), (Observation of animals and plants) }\end{array}$ \\
\hline
\end{tabular}

Table 4. Impression change degree before and after the reclamation project and changes in utilization before and after the reclamation project $(n=27)$.

\begin{tabular}{|c|c|c|c|c|c|c|c|c|c|c|c|c|c|c|c|}
\hline \multicolumn{16}{|c|}{ Degree of Use Changes (Ratio) } \\
\hline & & 0 & 1 & 2 & 3 & 4 & 5 & 6 & 7 & 8 & 9 & 10 & 11 & 12 & Total \\
\hline \multirow{7}{*}{$\begin{array}{l}\text { Degree of } \\
\text { impression } \\
\text { changes }\end{array}$} & & 1 & 1 & 0 & 0 & 0 & 2 & 0 & 1 & 0 & 2 & 1 & 1 & 1 & 10 \\
\hline & 3 & $(3.7 \%)$ & $(3.7 \%)$ & $(0.0 \%)$ & $(0.0 \%)$ & $(0.0 \%)$ & $(7.4 \%)$ & $(0.0 \%)$ & $(3.7 \%)$ & $(0.0 \%)$ & $(7.4 \%)$ & $(3.7 \%)$ & $(3.7 \%)$ & $(3.7 \%)$ & $(37.0 \%$ \\
\hline & & 0 & 0 & 1 & 1 & 0 & 0 & 0 & 1 & 0 & 0 & 0 & 0 & 0 & 3 \\
\hline & 2 & $(0.0 \%)$ & $(0.0 \%)$ & $(3.7 \%)$ & $(3.7 \%)$ & $(0.0 \%)$ & $(0.0 \%)$ & $(0.0 \%)$ & $(3.7 \%)$ & $(0.0 \%)$ & $(0.0 \%)$ & $(0.0 \%)$ & $(0.0 \%)$ & $(0.0 \%)$ & $(11.1 \%$ \\
\hline & & 0 & 0 & 0 & 1 & 0 & 0 & 1 & 0 & 0 & 0 & 0 & 0 & 0 & 2 \\
\hline & 1 & $(0.0 \%)$ & $(0.0 \%)$ & $(0.0 \%)$ & $(3.7 \%)$ & $(0.0 \%)$ & $(0.0 \%)$ & $(3.7 \%)$ & $(0.0 \%)$ & $(0.0 \%)$ & $(0.0 \%)$ & $(0.0 \%)$ & $(0.0 \%)$ & $(0.0 \%)$ & $(7.4 \%)$ \\
\hline & 0 & $\begin{array}{c}3 \\
(11.1 \%\end{array}$ & $\begin{array}{c}4 \\
(14.9 \%\end{array}$ & $\begin{array}{c}1 \\
(3.7 \%)\end{array}$ & $\begin{array}{c}1 \\
(3.7 \%)\end{array}$ & $\begin{array}{c}0 \\
(0.0 \%)\end{array}$ & $\begin{array}{c}1 \\
(3.7 \%)\end{array}$ & $\begin{array}{c}0 \\
(0.0 \%)\end{array}$ & $\begin{array}{c}1 \\
(3.7 \%)\end{array}$ & $\begin{array}{c}0 \\
(0.0 \%)\end{array}$ & $\begin{array}{c}1 \\
(3.7 \%)\end{array}$ & $\begin{array}{c}0 \\
(0.0 \%)\end{array}$ & $\begin{array}{c}0 \\
(0.0 \%)\end{array}$ & $\begin{array}{c}0 \\
(0.0 \%)\end{array}$ & $\begin{array}{c}12 \\
(44.5 \%\end{array}$ \\
\hline \multirow{2}{*}{ Total } & & 4 & 5 & 2 & 3 & $\frac{(0.0)}{0}$ & 3 & $\frac{(0.0 / 0)}{1}$ & 3 & $\frac{(0.0 / 0)}{0}$ & 3 & $\frac{(0.070)}{1}$ & $\frac{(0.070)}{1}$ & $\frac{(0.070)}{1}$ & \\
\hline & & $(14.9 \%)$ & $(18.6 \%)$ & $(7.4 \%)$ & $(11.1 \%)$ & $(0.0 \%)$ & $(11.1 \%$ & $(3.7 \%)$ & $(11.1 \%)$ & $(0.0 \%)$ & $(11.1 \%$ & ) $(3.7 \%)$ & $(3.7 \%)$ & $(3.7 \%)$ & \\
\hline
\end{tabular}

Regarding the publication of the survey and survey results, we obtained consent for publication only for academic purposes after ensuring that the target settlement remains unspecified.

\subsection{Analysis Method}

The actual situation of Fukushima-gata lagoon use before and after the reclamation project could be grasped by a simple tabulation of the questionnaire survey. Next, regarding the change and formation factors of attachment toward the Fukushima-gata lagoon, we considered the relationship between variables by cross-tabulation of the objective variable, attachment to the Fukushima-gata lagoon, and the explanatory variable, the actual situation of Fukushima-gata lagoon before and after the reclamation project. In addition, to examine the relationship between attachment to the Fukushima-gata lagoon and multiple living factors, the utilization diversity (the number of types of use in the answer of the questionnaire) as multiple living factors was used as a surrogate index and correlation analysis was carried out. Regarding the measurement of attachment, we assumed that households who frequently visited the Fukushima-gata lagoon were those who had attachment toward the Fukushima-gata lagoon. Specifically, frequency of visits to the Fukushima-gata lagoon was set to degree of attachment.

In addition, in this paper, "change in attachment" refers to a change in the impression evaluation of the Fukushima-gata lagoon before and after the reclamation project. The impression change degree 
for the Fukushima-gata lagoon before and after reclamation project was calculated; it was considered 0 when no change was observed, and 1 was added when there was a change in the impression about "landscape", "water transparency", and "flood countermeasure". It was set as an index that takes values from 0 to 3 . Similarly, degree of change in use was calculated as the degree of change in the use of the Fukushima-gata lagoon before and after the reclamation project. The degree of use change was set to 0 when there was no change in usage before and after the reclamation project and the value increased by 1 when there was a change in the use of the Fukushima-gata lagoon before and after the reclamation project at 27 levels, ranging from 0 to 26 . It was used as an indicator. Thereafter, to examine the relationship between the change in attachment to the Fukushima-gata lagoon and the change in use of the Fukushima-gata lagoon before and after the reclamation project, correlation analysis was conducted between impression change degree and degree of use changes.

\section{Results}

\subsection{Respondent Attribute Information}

\subsubsection{Residence Years}

Figure 5 shows the residence years of the targets. The ratio for over 50 years was $67.7 \%$. Therefore, the majority of the targets had knowledge about some situations in the Fukushima-gata lagoon before the reclamation project. You can see the respondent attribute as basic information in Tables A1 and A2.

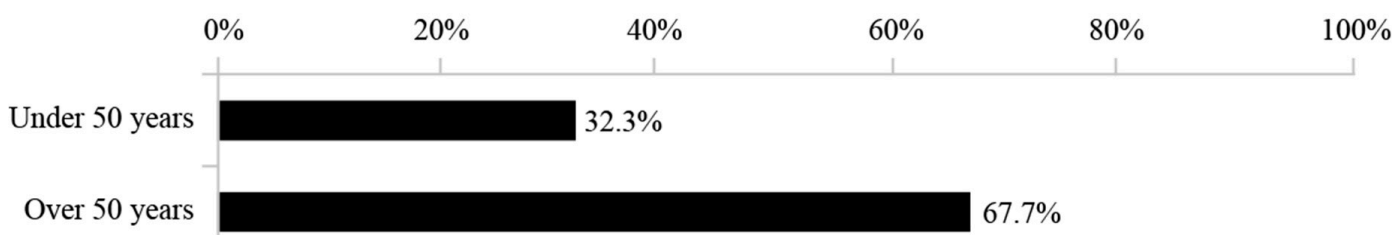

Figure 5. Residence years of targets $(n=31)$.

\subsubsection{Occupation}

Figure 6 shows the occupations of the targets. The ratio of private enterprises $(45.1 \%)$ and part-time farmer (35.5\%) were relatively high than the others.

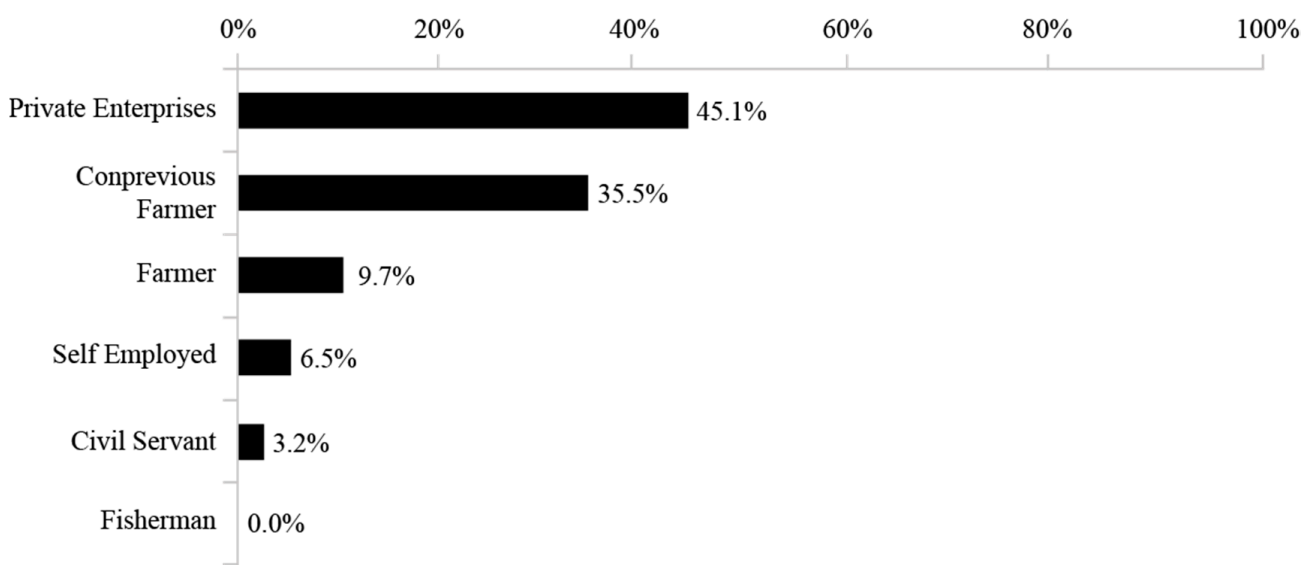

Figure 6. Occupations of targets $(n=31)$.

\subsubsection{Impression Changes in the Fukushima-gata Lagoon}

Figure 7 shows the ratio of answers to "no change in the Fukushima-gata lagoon before and after the reclamation project". We examined whether there were differences depending on the number of years of residence from the viewpoints of landscape, water transparency, and safety. The ratio of 
households who had lived there for more than 50 years and answered that the Fukushima-gata had not changed before and after the state drainage was low from all viewpoints.

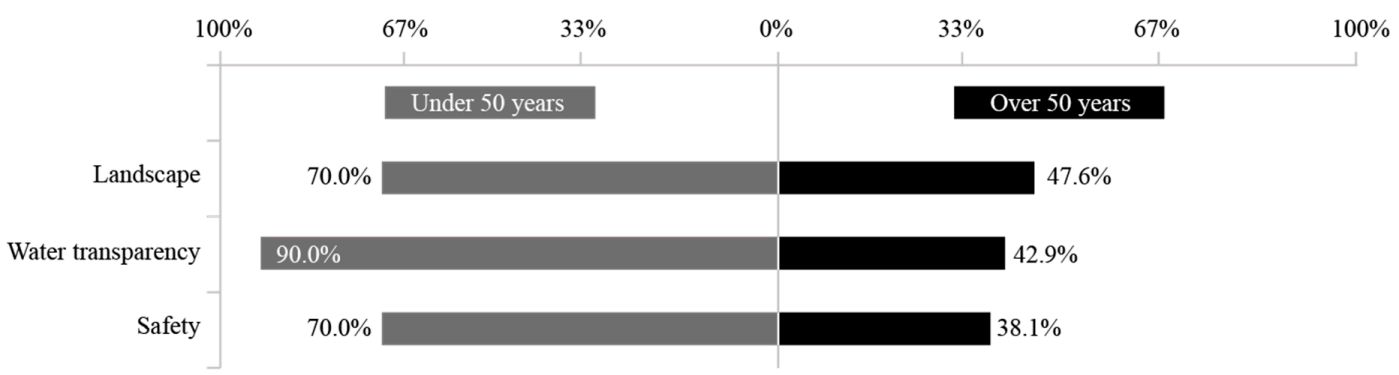

Figure 7. Ratio of Answers "no change in the Fukushima-gata lagoon before and after the reclamation project" $(\mathrm{n}=31)$.

\subsection{Attachment towards Fukushima-gata Lagoon and Use of Fukushima-gata Lagoon before and after the} Reclamation Project

The actual situation of attachment to the Fukushima-gata lagoon and the actual use of the Fukushima-gata lagoon were as described below.

\subsubsection{Actual Situation of the Attachment toward Fukushima-gata Lagoon}

The frequency of visits to Fukushima-gata lagoon after the reclamation project was defined as an indicator clearly showing attachment to the Fukushima-gata lagoon in this paper. We assumed that any household visiting the Fukushima-gata lagoon, regardless of their frequency, had a sense of affection toward the Fukushima-gata lagoon. Households that answered "do not go at all" had no attachment to the Fukushima-gata lagoon. Figure 8 shows the ratio of answers to frequency of visit by residence years after the reclamation project. The obvious difference between more than 50 years and under 50 years was the ratio of answers stating "every day". The other answers did not have obvious differences.

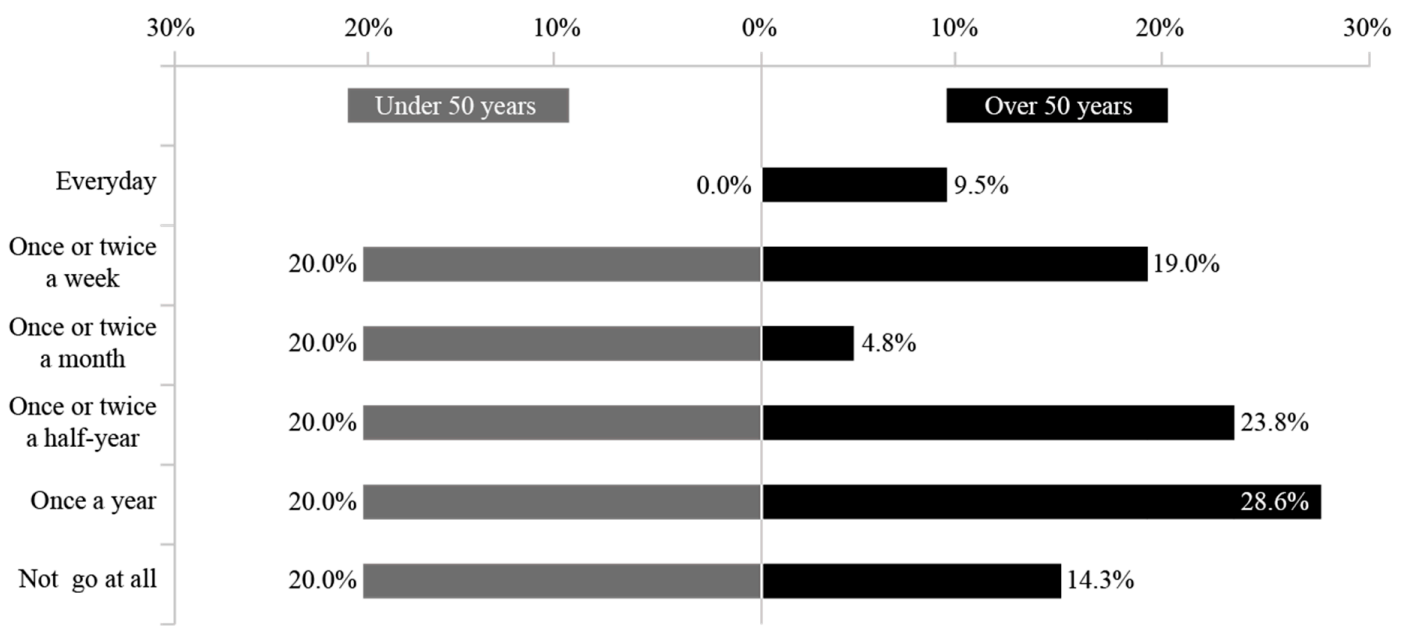

Figure 8. Frequency of visit by residence years after the reclamation project $(n=31)$.

\subsubsection{Actual Situation of Use the Fukushima-gata Lagoon before and after Reclamation Project}

The actual situation of the use of the Fukushima-gata lagoon before and after the reclamation project is described in Figure 9. You can see the detail of the actual situation of use of Fukushima-gata lagoon before and after the reclamation project in Table A3. The trends were divided into those whose frequency had dropped sharply after the reclamation project (collecting and selling wild rice, playing in the water, boarding the boat, capturing the fish, fishing, selling reeds as building material, hunting 
wild birds, using mud in the lagoon for rice fertilizer), those whose frequency had dropped slightly after the reclamation project (observation of animals and plants, viewing the lagoon), and those whose frequency had increased after the reclamation project (walking, photography).

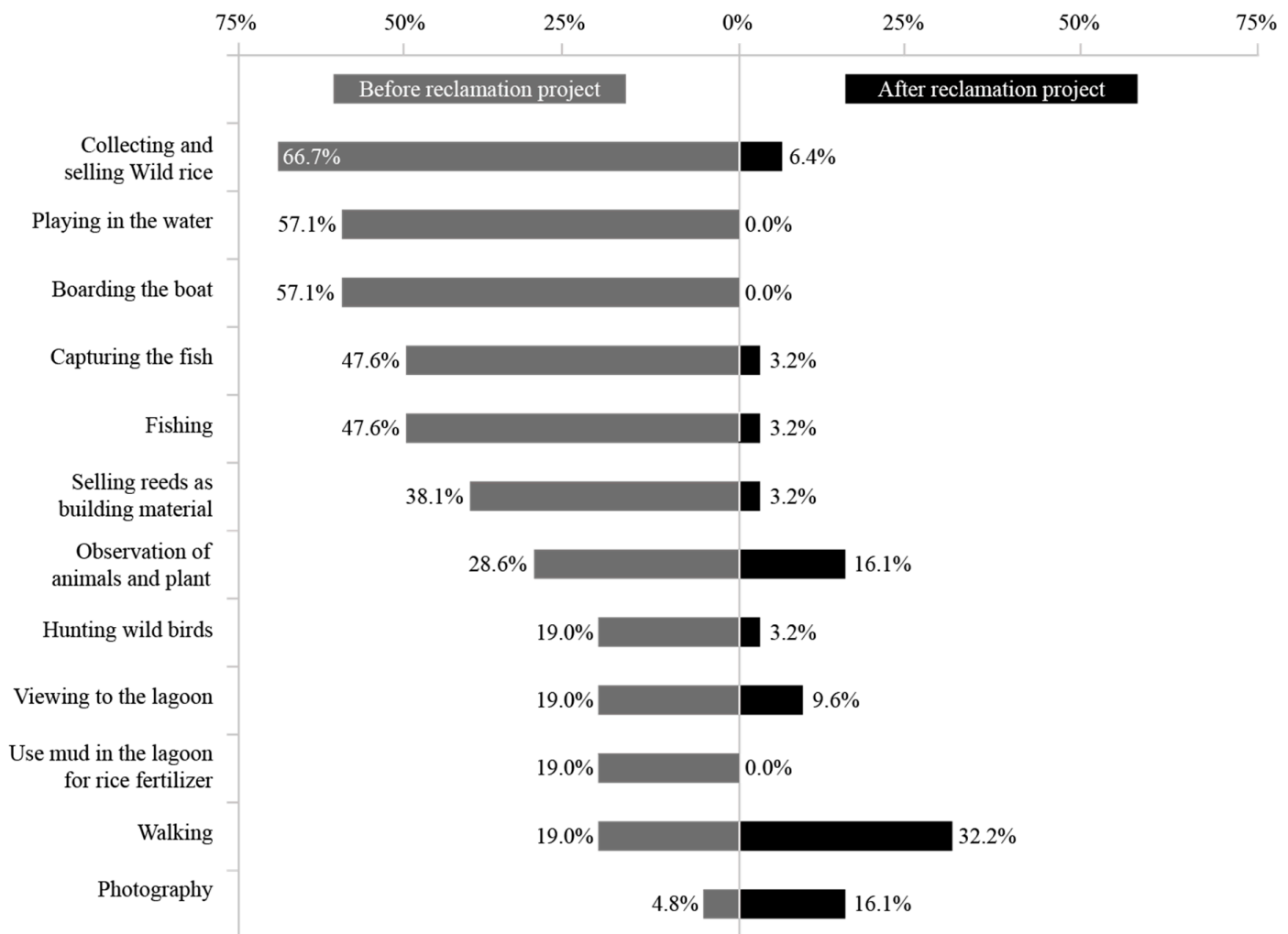

Figure 9. The actual situation of uses of the Fukushima-gata lagoon before and after the reclamation project $(n=31)$.

4.2.3. Cross-Tabulation of the Actual Situation of Uses of Fukushima-gata Lagoon before and after the Reclamation Project and Attachment towards the Fukushima-gata Lagoon.

Figure 10 shows the cross-tabulation results of the degree of attachment to the Fukushima-gata lagoon and the actual situation of utilization of the Fukushima-gata lagoon before and after the reclamation project. You can see the detail of the extent of attachment Fukushima-gata lagoon and actual use situation of Fukushima-gata lagoon in Tables A4 and A5. There was no difference in the response ratio of each question item based on the extent of attachment among households that showed attachment. On the other hand, households with a high degree of attachment tended to have higher usage diversity before the reclamation project in terms of utilization diversity, and households with "everyday" use tended to have an average utilization diversity before the reclamation project of 9.5 (standard deviation 0.7); households whose visiting frequency was nil had an average utilization diversity of 0.8 (standard deviation 1.8 ) before the project.

\subsection{Relationship between Degree of Attachment towards Fukushima-gata Lagoon and Utilization Diversity of Fukushima-gata Lagoon}

Considering that households with a high visiting frequency tended to have higher utilization diversity before the reclamation project, to examine the relationship between the degree of attachment toward Fukushima-gata lagoon and multiple livelihood factors, we created a scatter plot of the frequency of visits after the reclamation and utilization diversity before and after the reclamation project (see Figure 11). Using correlation analysis, the frequency of visits after the reclamation project and utilization diversity before the reclamation project had a correlation coefficient: $r=0.7404151$, 
$p$-value: $p=0.00012$, and was significant at the significance level of $0.1 \%$. Meanwhile, the frequency of visits after the reclamation project and utilization diversity after the reclamation project had a correlation coefficient: $\mathrm{r}=0.3852044, p$-value: $p=0.03236$, and was significant at a significance level of $5 \%$.

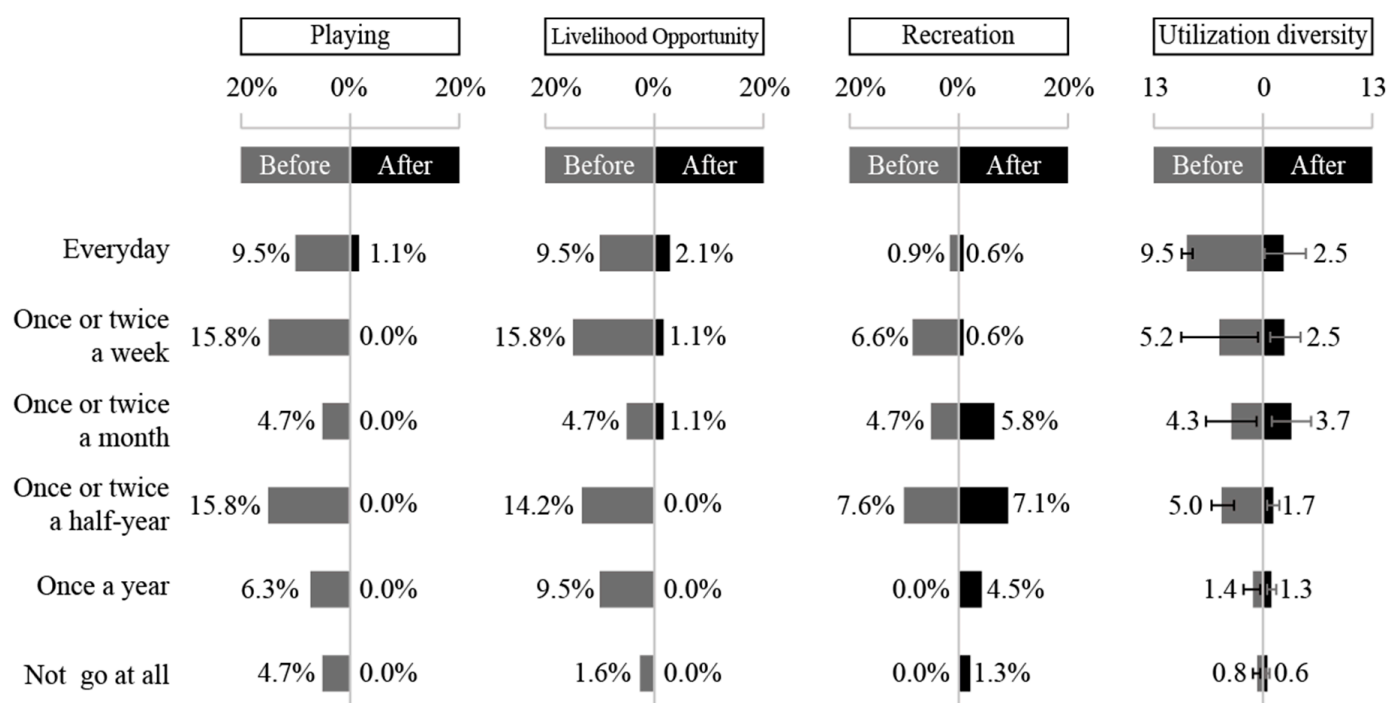

Figure 10. Ratio of answers to "no change in the Fukushima-gata lagoon before and after the reclamation project".

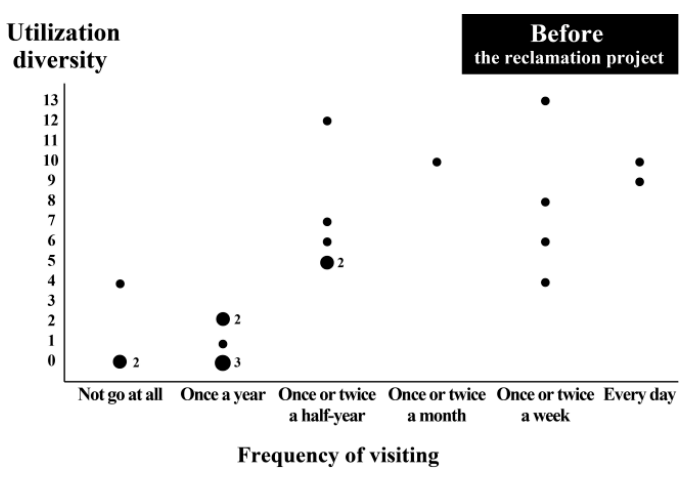

(a)

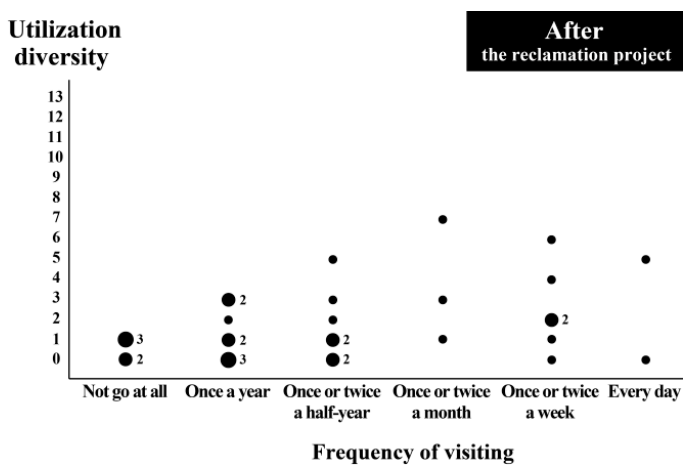

(b)

Figure 11. Frequency of visits after the reclamation project and utilization diversity before and after the reclamation project. (a): utilization diversity before the reclamation project; (b): utilization diversity after the reclamation project.

\subsection{Relationship between Changes in Attachment to Fukushima-gata Lagoon and Changes in Use of Fukushima-gata Lagoon}

We now consider the impression changes toward "landscape", "water transparency", and "flood countermeasure" as a change in the attachment to the Fukushima-gata lagoon. You can see the detail of the results in Tables A6 and A7. Figure 12 shows the cross-tabulation of the changes in attachment toward the Fukushima-gata lagoon and the actual situation of the utilization of the Fukushima-gata lagoon before and after the reclamation project.

Next, to examine the relationship between the changes in attachment toward Fukushima-gata lagoon and the changes in utilization of Fukushima-gata lagoon before and after the reclamation project, a cross-tabulation of impression change degrees before and after the reclamation project and degree of use changes before and after the reclamation project was implemented (Table 4). After conducting a correlation analysis, the correlation coefficient was found to be: $\mathrm{r}=0.5482957, p$-value: $p=0.0014$, and it was significant at a significance level of $1 \%$. 


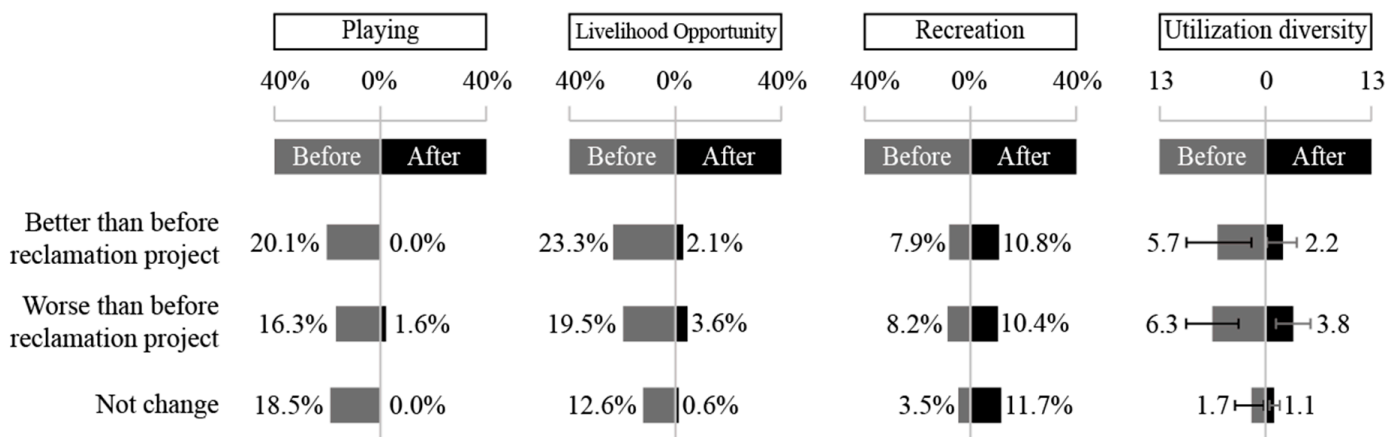

Figure 12. Ratio of answers to "no change in Fukushima-gata lagoon before and after the reclamation project".

In addition, the following four groups were characteristic of the relationship between the degree of impression change before and after the reclamation project of target households and the degree of use change before and after the reclamation project. (1) The group that showed no change in attachment or use is one in which impression change degree had an average value of 0.0 (standard deviation 0.0 ), use change degree: average value 0.6 (standard deviation 0.5); (2) the group that showed a change in attachment or use was one whose impression change degree had an average value of 3.0 (standard deviation 0.0), and use change degree of average value 10.4 (standard deviation 1.1); (3) the group that showed a change in attachment but no change in use had an impression change degree with an average value of 3.0 (standard deviation 0.0 ), and use change degree of average value 0.5 (standard deviation $0.7) ;(4)$ the group whose attachment showed no changed and whose use changed had an impression change degree of average value 0.0 (standard deviation 0.0 ) and use change degree of average value 8.0 (standard deviation 1.4).

\section{Discussion}

\subsection{Attachment towards Fukushima-gata Lagoon before and after the Reclamation Project and Use Situation of Fukushima-gata Lagoon}

This study conducted a questionnaire survey (response rate $83.7 \%$ ) on settlements (37 households) based on: (1) the distances or time of travel from the residence to the waterfront of the Fukushima-gata lagoon before and after the reclamation project; (2) attachment toward Fukushima-gata lagoon; and (3) the actual situation of use Fukushima-gata lagoon.

Based on the survey results, households with attachment toward Fukushima-gata lagoon accounted for $83.9 \%$, those with a certain degree of attachment towards Fukushima-gata lagoon after the reclamation project were confirmed as the target settlement. Regarding the extent of attachment to Fukushima-gata lagoon, households with various degrees of attachment, ranging from "once a year" to "every day", were confirmed.

Next, regarding the actual situation of Fukushima-gata lagoon use, 93.5\% of households responded saying they use the Fukushima-gata lagoon for various purposes, and hence, we conclude that the Fukushima-gata lagoon was a water environment for the livelihood of the residents of the region. Households that responded that they had used Fukushima-gata lagoon before and after the reclamation project were: before reclamation project- $76.2 \%$, and after reclamation project- $70.9 \%$. According to previous research $[45,49]$, as a use before the reclamation project, "they used to hunt various birds, such as sparrows, swallows", "collect reeds for harvesting as a material for roofing and as an income source", "many households owned at least one small boat, which was indispensable for their living, such as for fishing of crucian carp and shrimp and for transporting harvested rice", "in addition to agricultural work, they used to catch fish for self-consumption and did several side jobs, picked water chestnuts and lotus, cut reeds", and other such uses. In the interview survey, we obtained testimonies on enjoying playing in the water, such as "I practiced swimming in Fukushima-gata lagoon when I 
was a child", "I took a boat and competed with my friends in rowing". However, after the reclamation project, "I walk around Fukushima-gata lagoon in the morning and the evening and remember how I played in Fukushima-gata lagoon in the good old days", or "when spring comes, I see the cherry blossoms on the south side of Fukushima-gata lagoon", and "people living in urban areas come to view cherry blossoms as well". There were many trends in the recreational use of Fukushima-gata lagoon, and this led to a decrease in the harvesting of reeds, use of boats, catching fish, hunting of wild birds, and playing in the water.

According to the Ministry of the Environment of Japan [50], the use of water by residents and for industrial activities as an indicator of a healthy water environment is positioned as an important factor. Based on the research of this study the use of both was confirmed in the Fukushima-gata lagoon, but after reclamation project, fishing for livelihood and collecting aquatic plants drastically reduced. According to the article [51] published in the Asahi Shinbun on 29 June 1989, "in a survey conducted after the reclamation project, the aquatic plants that characterize Fukushima-gata lagoon have declined drastically, and about 200 species of plants recorded before the reclamation project were not confirmed". The habitat was considered adversely affected by the lack of diversity in the water quality and water environment after the reclamation project, which resulted in a decrease in the number of species. As a background to this, Japan, at the time of reclamation project (1968) [51], was going through a period of high economic growth, and environmental preservation in the regional context was not given sufficient importance. Also, in the interview survey (Table 2) of this study, since it was seen that "the water transparency of Fukushima-gata lagoon deteriorated due to the reclamation project and no fish was acquired", the project apparently caused damage to the diversity of the natural environment of the Fukushima-gata lagoon, affecting the lives of the regional residents around it, and led to a drastic decrease in plant harvesting and fishing for their livelihoods.

\subsection{Factors Influencing Attachment towards Fukushima-gata Lagoon}

Based on previous studies, in the relationship between the use of a single body as a behavioral act and the formation of attachment, it has been reported that it is not a single factor, but complex factors that have contributed to the formation of attachment. Therefore, to examine the relationship between the attachment towards the Fukushima-gata lagoon and complex living factors, the correlation using substitution index as utilization diversity (the number of types of use in the answer result of the questionnaire) as a compound life factor analysis was carried out. A positive correlation was found between utilization diversity, which is a complex factor, before and after the reclamation project. Therefore, utilization diversity before the reclamation project, that is, composite factors concerning livelihood use, such as utilization of playing in the water, harvesting of reeds, use of a boat, and utilization diversity after the reclamation project, that is, composite factors on recreational usual use, such as walking and cherry blossom viewing, both contributed to the formation of attachment toward the Fukushima-gata lagoon. These findings of the attachment in long-term and short-term are new and have not been reported so far.

In addition, composite factors concerning livelihood use, such as playing in the water and harvesting reeds and use of boats, are those that can be considered on the premise of preservation of the diversity of water environments in Fukushima-gata lagoon, described in the preceding paragraph. Therefore, it is suggested that preservation of the diversity of water environments in Fukushima-gata lagoon contributes to the formation of an attachment toward the future Fukushima-gata lagoon. Therefore, attachment not only in the short-term but also in the long-term may have influenced the local residents' behavior to preserve Fukushima-gata lagoon (Figure 13). 


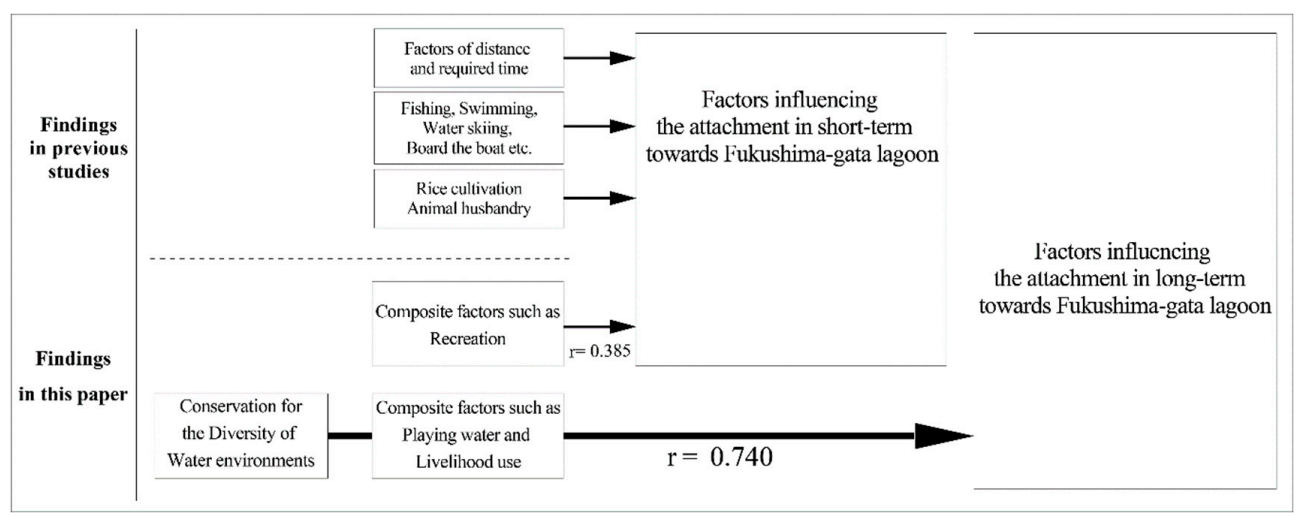

Figure 13. Factors affecting the formation of attachment.

Moreover, it was stated that in other previous studies, the distances or time of travel to the target area were important factors influencing attachment toward the target area. In this study, from the viewpoint of changes in lifestyle, only the settlement where there were changes in the separation from the waterfront after the reclamation project, where the influences of the distance/the required time were invariables, was investigated. Therefore, not only the distance or time of travel but also the utilization diversity before the reclamation project may have influenced the formation of an attachment to Fukushima-gata lagoon.

Next, we examined the factors influencing attachment, with the change in attachment at two time points-before and after the reclamation project-as an objective variable. The degree of impression change as a change in attachment and the degree of change in use before and after the reclamation project were found to have a positive correlation after conducting a correlation analysis $(r=0.54)$. In short, the relationship between the change in attachment towards the Fukushima-gata lagoon and the changes in the lifestyle conditions of regional residents was suggested. Therefore, we investigated whether a causal relationship was established between the changes in attachment (impression change degree) and changes in use. Since the correlation was positive, it was based on (1): the group whose attachment and use did not change as the starting point, and a linear relationship with the end point at (2): the group whose attachment and use changed. Furthermore, since the correlation coefficient was 0.54 , it should be considered that there was also the influence of (3): the group whose attachment changed, and use did not change, and (4): the group whose attachment did not change, and use changed.

Below, we consider whether a causal relationship was established based on the actual situation of the above four groups.

First, households belonging to (1): the group whose attachment and use did not change, have used little of the Fukushima-gata lagoon, both before and after the reclamation project. Therefore, in this study, they were "households who had no attachment to Fukushima-gata lagoon" and this agrees with the characteristic of the origin of the above correlation.

Second, for households belonging to (2): the group whose attachment and use changed, playing in the water and livelihood opportunities before the reclamation project declined, and recreational use after the reclamation project was increased. In addition, as the content of change in attachment (impression), there was a tendency for deterioration of the water environment and improvement in safety. Therefore, the increase in recreational use caused by the improvement of sidewalks and revetment, along with the decrease in playing in the water and livelihood opportunities due to a deterioration in the water environment and improvement in safety was a feature of the endpoint. This feature was based on the content of usage actualities discussed so far, and "the landscape got worse, fish and birds ceased to live" because of "the way the embankment was built" was also obtained as verbal evidence in the interview survey (Table 2). 
Third, households belonging to (3): the group whose attachment changed and whose use did not change used the Fukushima-gata lagoon sparingly before and after the reclamation project. Therefore, in this study, they were considered households that do not have an attachment to Fukushima-gata lagoon. Besides this, this group has contributed to the decrease of the correlation coefficient in the linear relationship between the origin and the endpoint.

Fourth, households belonging to (4): the group whose attachment did not change, and use changed led to a decrease in playing in the water and livelihood opportunities, but after the reclamation project, almost all of the Fukushima-gata lagoon was not used by them, and they did not visit it. There were many elderly people in this group of respondents. For them, it had become difficult to visit Fukushima-gata lagoon due to a change in distance or time of travel/deterioration of physical function due to aging, or they were not interested in playing in the water and livelihood opportunities were not as they were before state reclamation, or they had a bad impression and there was no attachment to Fukushima-gata lagoon. Therefore, it was not positioned in the linear relationship between the origin and the end point of the correlation, which contributes to the reduction of the correlation coefficient.

Based on the above, not only the positive correlation between the change in attachment (degree of impression change) and change in utilization, but also the causal relationship that a decrease in playing in the water and livelihood opportunities due to the deterioration of the water environment and increase in recreational use accompanying improved safety, was established. Previous studies have reported that composite factors contribute to influencing attachment in the short-term [17,23], but these are factors of attachment formation at a certain time-point, and changes in attachment in long-term factors have not been adequately studied. From the viewpoint of "change in attachment" handled in this study, it is suggested that not only the influence of factors at a certain time-point in short-term but also the dynamic change of composite factors in the long-term may influence attachment. This finding was significant, as knowledge contributing to the study of the problem of elucidation of the form factors of attachment considering changes in the lifestyle of regional residents (Table 5).

Table 5. Relationship between degree of changes in impression and degree of changes in utilization

\begin{tabular}{|c|c|c|c|}
\hline \multicolumn{4}{|c|}{ Degree of Use Changes } \\
\hline & & High & Low \\
\hline \multirow[t]{2}{*}{$\begin{array}{l}\text { Degree of impression } \\
\text { changes }\end{array}$} & High & $\begin{array}{l}\text { Playing in the water and } \\
\text { livelihood opportunity decreased } \\
\text { due to deterioration of water } \\
\text { environment } \\
\text { Recreational use increased due to } \\
\text { improving safety }\end{array}$ & Little use \\
\hline & Low & $\begin{array}{l}\text { Little use after reclamation project } \\
\text { due to factors such as changes in } \\
\text { distance or time of travel }\end{array}$ & Little use \\
\hline
\end{tabular}

\subsection{Hypothesis Validation}

Based on the above discussion, we verified the hypotheses and the theoretical framework.

Hypothesis 1: Fukushima-gata lagoon, had been largely used as a means of food (for catching fish and edible plants) and housing (getting reeds for building materials) before the reclamation project. However, the lagoon can no longer be used by regional residents after the reclamation project.

Based on the findings of this study, although the uses related to food and housing decreased greatly, increasing recreational use was confirmed after the reclamation project, and hence, Hypothesis 1 was not supported.

Hypothesis 2, not only the use of the water environment after the reclamation project but also the use of the water environment before the reclamation project affected the formation of attachment in the long-term, was supported. Based on the findings of the study, a correlation was found between 
the frequency of visits and playing in the water/livelihood opportunities as the use of the water environment before the reclamation. Besides this, a correlation was also found between the frequency of the visits and sidewalk/cherry blossom viewing as the use of the water environment after the reclamation. Therefore, in the target, Hypothesis 2 was supported.

Hypothesis 3, factors of playing in the water, livelihood opportunities, and recreational use are involved in forming attachment in the long-term toward the Fukushima-gata lagoon, was partially supported. Based on the findings of this study, composite factors of playing in the water and livelihood opportunities and composite factors of recreational use showed a positive correlation with attachment toward the Fukushima-gata lagoon. Composite factors of recreational use did not contribute to attachment in the long-term, but composite factors of recreational use contributed to attachment in the short-term. Therefore, Hypothesis 3 was partially supported.

A strong positive correlation was found between factors of playing in the water/livelihood opportunities and attachment toward the Fukushima-gata lagoon. It was suggested that the preservation of the diversity of water environments in the Fukushima-gata lagoon, which was a prerequisite for the use of playing in the water/livelihood opportunities, may become a condition to form attachment toward the Fukushima-gata lagoon in the future.

Based on the results of the validation of the hypotheses, the findings in this research were positioned as new knowledge instead of unidentified information (Figure 2). Figure 14 shows the research framework with the findings.

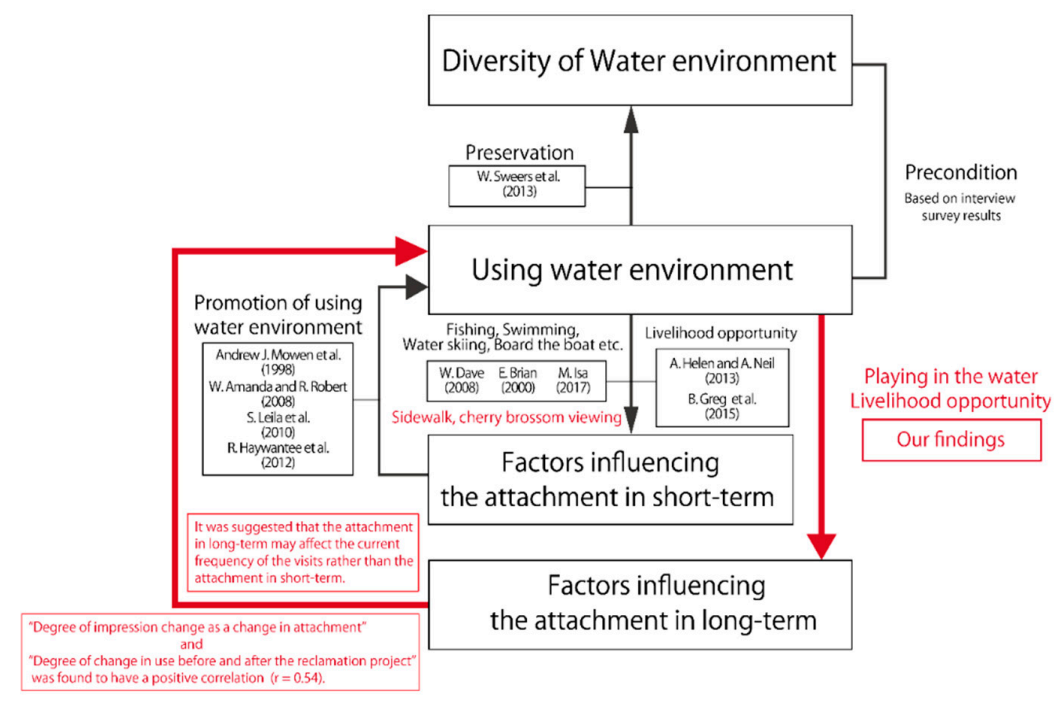

Figure 14. Findings based on the theoretical framework.

\subsection{Limitations}

This study had the following three limitations.

First of all, in this research, the emphasis was placed on clarifying correspondence between attachments to the Fukushima-gata lagoon before and after the reclamation project and to gain a grasp of the actual usage of the Fukushima-gata lagoon and the attachment towards the Fukushima-gata lagoon and changes in the attachment and lifestyle, we conducted a survey. However, as to factors influencing the attachment towards the Fukushima-gata lagoon, since various factors are considered to be composite factors which allow an attachment towards the Fukushima-gata lagoon is thought to be formed, in the above discussion on factors of attachment towards Fukushima-gata lagoon, we did not identify single factors influencing the attachment.

Next, in this study, only the village where the distance to the waterfront in Fukushima-gata lagoon changed the most was examined. However, it is most desirable to compare the targets where the distance to the waterfront of Fukushima-gata lagoon has not changed and compare these with 
the targets where the distance changed the greatest, but it could not be achieved by the scope of this research.

Also, in this study, we used indicators of "landscape", "water quality", and "flood countermeasure" as impression changes in the Fukushima-gata lagoon. However, as shown by the Ministry of the Environment of Japan [52], it is assumed that factors relating to the five senses greatly influence the changes in impression for the Fukushima-gata lagoon. Since this study does not deal with the five senses as an indicator of impression change toward the Fukushima-gata lagoon, we did not consider the changes in impression regarding the five senses.

The above limitations will be considered as future subjects for study.

\section{Conclusions}

In this study, we aimed to identify the actual situation of attachment toward the Fukushima-gata lagoon and the actual situation of the Fukushima-gata lagoon before and after the reclamation project, and to identify the corresponding relationship between the changes in attachment as factors influencing attachment toward Fukushima-gata lagoon and changes in lifestyle. As a result, the following four points were found.

1. Use of Fukushima-gata lagoon was mainly related to food (capturing fish and plants) and housing (catching reeds used for building materials) before the reclamation project, but after the reclamation project, food and housing use greatly decreased, and recreational use (walking and cherry blossom viewing) became the main use.

2. Not only the use of the water environment after the reclamation project but also the use of the water environment before the reclamation project affected the formation of a long-term attachment.

3. A correlation was found between the frequency of visits and playing in the water/livelihood opportunities as uses of the water environment before the reclamation. Besides this, a correlation was also found between the frequency of visits and sidewalk/cherry blossom viewing as uses of the water environment after the reclamation.

4. A corresponding relationship was seen between the changes in attachment towards Fukushima-gata lagoon and the changes in the lifestyle of regional residents before and after the reclamation project.

Our findings lead to a key suggestion for the preservation of the future water environment. In order to cultivate persons who preserve the Fukushima-gata lagoon, it is necessary to preserve water environments that can be put to various uses. In addition, it is necessary to form a long-term attachment based on promoting the use of the water environment.

A possible proposal based on the research results is a program that allows you to experience water play and livelihood in diverse water environments using differences in water depth. For example, in Japan, there are different water-extracted plants, depending on the water depth, such as Rice, Poaceae, Wild rice, Reed, Nuphar japonica, and Nelumbo, and a program could be considered that takes steps such as cultivation, observation, harvesting, and daily use. Forming an attachment to the water environment through water play and livelihood use in diverse water environments combining cultures and water depths, not only in Japan but also in various countries around the world, might contribute to fostering a leader in preserving water environments in each country, long-term.

These water environments attract residents and contribute to increasing the sustainability of preserving water bodies, such as the Fukushima-gata lagoon.

Author Contributions: D.O. and R.F. conceived, designed, and conducted the interview survey, designed and conducted the questionnaire survey, analyzed the data; D.O. and R.F. conceived and wrote the paper.

Funding: This research received no external funding.

Acknowledgments: The authors would like to thank Soichiro Ogawa for useful discussions.

Conflicts of Interest: The authors declare no conflict of interest. 


\section{Abbreviations}

COLL Collecting and selling Wild rice, Water chestnuts, lotus

OBSE Observation of animals and plants

SELL Sell reeds as building material

VTF Viewing to Fukushima-gata lagoon

BURN Burn reeds to preserve the environment

USEM Use mud in Fukushima-gata lagoon for rice fertilizer

PART Participate in events and festivals held in Fukushima-gata lagoon

PHO Photography

VCB Viewing cherry blossoms

\section{Note}

1. "Use" in this study refers to a situation where activities are carried out for some purpose, such as "to play" or "to collect resources".

2. The Niigata City Lagoon Environment Research Institute for Environmental Studies is an organization established in 2014 with the objective of surveying and researching lagoons, building a network, collecting information, and sending lagoon information, and acting as contact. https://www.city.niigata.lg.jp/kurashi/ kankyo/kataken/kataken_gaiyou.html (accessed on 6 January 2019).

3. Regional Community Council: For the purpose of community development and promotion of citizen autonomy by collaboration between citizen and city, this is an organization composed of various groups, mainly based on elementary school district or junior high school district, centering around each neighborhood association and neighborhood association. https://www.city.niigata.lg.jp/kurashi/shimin/ community/comkyou.html (accessed on 6 January 2019).

\section{Appendix A}

Table A1. Respondent attribute $(n=31)$.

\begin{tabular}{ccc}
\hline & Gender & Number of Households (Ratio) \\
\hline Gender & Male & $23(74.2 \%)$ \\
$(\mathrm{n}=31)$ & Female & $7(22.6 \%)$ \\
& Unanswered & $1(3.2 \%)$ \\
\hline Age & years and under & $0(0.0 \%)$ \\
$(\mathrm{n}=31)$ & $10 \mathrm{~s}$ & $0(0.0 \%)$ \\
& $20 \mathrm{~s}$ & $0(0.0 \%)$ \\
& $30 \mathrm{~s}$ & $2(6.5 \%)$ \\
& $40 \mathrm{~s}$ & $4(12.9 \%)$ \\
& $50 \mathrm{~s}$ & $4(12.9 \%)$ \\
Family structure & $60 \mathrm{~s}$ & $10(32.2 \%)$ \\
$(\mathrm{n}=31)$ & $70 \mathrm{~s}$ & $9(29.0 \%)$ \\
& 80 years and over & $2(6.5 \%)$ \\
\hline & Single person & $5(16.1 \%)$ \\
& Couple & $6(19.4 \%)$ \\
& 2 generations & $11(35.5 \%)$ \\
& 3 generations & $9(29.0 \%)$ \\
\hline Residence years & years and under & $1(3.2 \%)$ \\
$(\mathrm{n}=31)$ & $10-19$ years & $1(3.2 \%)$ \\
& $20-29$ years & $3(9.7 \%)$ \\
& $30-39$ years & $1(3.2 \%)$ \\
& $40-49$ years & $4(12.9 \%)$ \\
& $50-59$ years & $5(16.2 \%)$ \\
& $60-69$ years & $8(25.8 \%)$ \\
& $70-79$ years & $7(22.6 \%)$ \\
& Over 80 years & $1(3.2 \%)$ \\
\hline
\end{tabular}


The survey asked about households' participation in events and gatherings, and their frequency of participation. From the results (Table A2), the participation frequency in regional meetings was $61.3 \%$ and in festivals was $41.9 \%$. The participation frequency in regional meetings was relatively higher than around other settlements [49]. Based on the survey of Niigata City (2018) [49], 68.6\% of the residents did not participate in the Regional Community Council (Note 3) in northward Niigata city, where the Fukushima-gata lagoon is located. Therefore, it was suggested that the target settlement was one in which there is a high participation rate in regional events/gatherings.

Table A2. Participation situation of events/gatherings $(n=31)$.

\begin{tabular}{ccccc}
\hline Event & $\begin{array}{c}\text { Frequency of } \\
\text { Participation }\end{array}$ & $\begin{array}{c}\text { Residence Years of } \\
\text { Less than 50 Years } \\
\text { (n = 10) (Ratio) }\end{array}$ & $\begin{array}{c}\text { Residence Years of } \\
\text { over 50 Years } \\
(\mathbf{n}=\mathbf{2 1}) \text { (Ratio) }\end{array}$ & $\begin{array}{c}\text { Total } \\
\text { (n = 31) (Ratio) }\end{array}$ \\
\hline \multirow{5}{*}{ Regional Meeting } & Almost every & $8(80.0 \%)$ & $11(52.4 \%)$ & $19(61.3 \%)$ \\
& Occasionally & $0(0.0 \%)$ & $3(14.3 \%)$ & $3(9.7 \%)$ \\
& 1 or 2 times & $0(0.0 \%)$ & $0(0.0 \%)$ & $0(0.0 \%)$ \\
& Not participated & $1(10.0 \%)$ & $3(14.3 \%)$ & $4(12.9 \%)$ \\
& Unanswered & $1(10.0 \%)$ & $4(19.0 \%)$ & $5(16.1 \%)$ \\
\hline \multirow{2}{*}{ Meeting to Chat } & Almost every & $1(10.0 \%)$ & $3(14.3 \%)$ & $4(12.9 \%)$ \\
& Occasionally & $1(10.0 \%)$ & $3(14.3 \%)$ & $4(12.9 \%)$ \\
& 1 or 2 times & $0(0.0 \%)$ & $1(4.8 \%)$ & $1(3.2 \%)$ \\
& Not participated & $1(10.0 \%)$ & $2(9.5 \%)$ & $3(9.7 \%)$ \\
Emergency & Unanswered & $7(70.0 \%)$ & $12(57.1 \%)$ & $19(61.3 \%)$ \\
\hline Training & Almost every & $2(20.0 \%)$ & $3(14.3 \%)$ & $5(16.1 \%)$ \\
& Occasionally & $0(0.0 \%)$ & $2(9.5 \%)$ & $2(6.5 \%)$ \\
& 1 or 2 times & $0(0.0 \%)$ & $2(9.5 \%)$ & $2(6.5 \%)$ \\
& Not participated & $0(0.0 \%)$ & $4(19.0 \%)$ & $4(12.9 \%)$ \\
& Unanswered & $8(80.0 \%)$ & $10(47.6 \%)$ & $18(58.0 \%)$ \\
\hline \multirow{6}{*}{ Festival } & Almost every & $5(50.0 \%)$ & $8(38.1 \%)$ & $13(41.9 \%)$ \\
& Occasionally & $0(0.0 \%)$ & $2(9.5 \%)$ & $2(6.5 \%)$ \\
& 1 or 2 times & $1(10.0 \%)$ & $0(0.0 \%)$ & $1(3.2 \%)$ \\
& Not participated & $1(10.0 \%)$ & $3(14.3 \%)$ & $4(12.9 \%)$ \\
& Unanswered & $3(30.0 \%)$ & $8(38.1 \%)$ & $11(35.5 \%)$ \\
\hline
\end{tabular}

Table A3. The actual situation of uses of the Fukushima-gata lagoon before and after the reclamation project $(n=31)$.

\begin{tabular}{|c|c|c|}
\hline \multirow{2}{*}{ Usage Items } & \multicolumn{2}{|c|}{ Number of Households (Ratio) } \\
\hline & $\begin{array}{l}\text { Before Reclamation } \\
\text { Project }(n=21) \text { (Ratio) }\end{array}$ & $\begin{array}{c}\text { After Reclamation Project } \\
\text { (n = 31) (Ratio) }\end{array}$ \\
\hline Playing in the water & $12(57.1 \%)$ & $0(0.0 \%)$ \\
\hline Drink water in Fukushima-gata lagoon & $2(9.5 \%)$ & $0(0.0 \%)$ \\
\hline COLL & $14(66.7 \%)$ & $2(6.4 \%)$ \\
\hline OBSE & $6(28.6 \%)$ & $5(16.1 \%)$ \\
\hline Hunting wild birds & $4(19.0 \%)$ & $1(3.2 \%)$ \\
\hline Capture the fish & $10(47.6 \%)$ & $1(3.2 \%)$ \\
\hline Boarding the boat & $12(57.1 \%)$ & $0(0.0 \%)$ \\
\hline Laundry / washing & $0(0.0 \%)$ & $0(0.0 \%)$ \\
\hline Participate in plant protection activities & $1(4.8 \%)$ & $0(0.0 \%)$ \\
\hline Break & $1(4.8 \%)$ & $4(12.9 \%)$ \\
\hline SELL & $8(38.1 \%)$ & $1(3.2 \%)$ \\
\hline Viewing to Fukushima-gata lagoon & $4(19.0 \%)$ & $3(9.6 \%)$ \\
\hline BURN & $3(14.3 \%)$ & $4(12.9 \%)$ \\
\hline Used as agricultural water & $3(14.3 \%)$ & $2(6.4 \%)$ \\
\hline Fishing & $10(47.6 \%)$ & $1(3.2 \%)$ \\
\hline USEM & $4(19.0 \%)$ & $0(0.0 \%)$ \\
\hline PART & $1(4.8 \%)$ & $2(6.4 \%)$ \\
\hline Walking & $4(19.0 \%)$ & $10(32.2 \%)$ \\
\hline Excursion & $1(4.8 \%)$ & $0(0.0 \%)$ \\
\hline Running & $0(0.0 \%)$ & $0(0.0 \%)$ \\
\hline Picnic & $0(0.0 \%)$ & $0(0.0 \%)$ \\
\hline Photography & $1(4.8 \%)$ & $5(16.1 \%)$ \\
\hline Drawing a picture & $0(0.0 \%)$ & $1(3.2 \%)$ \\
\hline Having a meal & $0(0.0 \%)$ & $1(3.2 \%)$ \\
\hline Singing a song & $0(0.0 \%)$ & $0(0.0 \%)$ \\
\hline Viewing cherry blossoms & $4(19.0 \%)$ & $12(38.7 \%)$ \\
\hline
\end{tabular}

Abbreviations: COLL: Collecting and selling Wild rice, Water chestnuts, lotus, OBSE: Observation of animals and plants, SELL: Sell reeds as building material, BURN: Burn reeds to preserve the environment, USEM: Use mud in Fukushima-gata lagoon for rice fertilizer, PART: Participate in events and festivals held in Fukushima-gata lagoon. 
Table A4. The extent of attachment to the Fukushima-gata lagoon and actual use situation of the Fukushima-gata lagoon before reclamation project ( $\mathrm{n}=21)$.

\begin{tabular}{|c|c|c|c|c|c|c|c|c|c|c|c|c|c|c|c|c|}
\hline & \multirow[b]{2}{*}{ Usage Items } & \multicolumn{3}{|c|}{ Playing } & \multicolumn{3}{|c|}{ Livelihood Opportunity } & \multicolumn{5}{|c|}{ Recreational Use } & \multicolumn{4}{|c|}{ Utilization Diversity } \\
\hline & & $\begin{array}{l}\text { Playing in } \\
\text { the Water }\end{array}$ & $\begin{array}{l}\text { Boarding } \\
\text { the Boat }\end{array}$ & Fishing & COLL & $\begin{array}{l}\text { Capture } \\
\text { the Fish }\end{array}$ & SELL & OBSE & VTF & Walking & PHO & VCB & Average & S.D. & Max & Min \\
\hline & \multicolumn{16}{|c|}{ Degree of attachment } \\
\hline \multirow{5}{*}{$\begin{array}{c}\text { Frequency } \\
\text { of Visits }\end{array}$} & Once or twice a week & $4(19.0 \%)$ & $4(19.0 \%)$ & $2(9.5 \%)$ & $4(19.0 \%)$ & $4(19.0 \%)$ & $2(9.5 \%)$ & $2(9.5 \%)$ & $2(9.5 \%)$ & $1(4.7 \%)$ & $1(4.7 \%)$ & $1(4.7 \%)$ & 5.2 & 5.0 & 13 & 0 \\
\hline & Once or twice a month & $1(4.7 \%)$ & $1(4.7 \%)$ & $1(4.7 \%)$ & $1(4.7 \%)$ & $1(4.7 \%)$ & $1(4.7 \%)$ & $1(4.7 \%)$ & $1(4.7 \%)$ & $1(4.7 \%)$ & $1(4.7 \%)$ & $1(4.7 \%)$ & 4.3 & 5.1 & 10 & 0 \\
\hline & Once or twice a half-year & $3(14.2 \%)$ & $4(19.0 \%)$ & $3(14.2 \%)$ & $4(19.0 \%)$ & $3(14.2 \%)$ & $2(9.5 \%)$ & $2(9.5 \%)$ & $1(4.7 \%)$ & $2(9.5 \%)$ & $0(0.0 \%)$ & $3(14.2 \%)$ & ) 5.0 & 4.2 & 12 & 0 \\
\hline & Once a year & $2(9.5 \%)$ & $1(4.7 \%)$ & $1(4.7 \%)$ & $3(14.2 \%)$ & $1(4.7 \%)$ & $2(9.5 \%)$ & $0(0.0 \%)$ & $0(0.0 \%)$ & $0(0.0 \%)$ & $0(0.0 \%)$ & $0(0.0 \%)$ & 1.4 & 2.1 & 6 & 0 \\
\hline & Not go at all & $1(4.7 \%)$ & $1(4.7 \%)$ & $1(4.7 \%)$ & $1(4.7 \%)$ & $0(0.0 \%)$ & $0(0.0 \%)$ & $0(0.0 \%)$ & $0(0.0 \%)$ & $0(0.0 \%)$ & $0(0.0 \%)$ & $0(0.0 \%)$ & 0.8 & 1.8 & 4 & 0 \\
\hline
\end{tabular}

Table A5. The extent of attachment to the Fukushima-gata lagoon and actual use situation of the Fukushima-gata lagoon after reclamation project $(\mathrm{n}=31)$.

\begin{tabular}{|c|c|c|c|c|c|c|c|c|c|c|c|c|c|c|c|c|}
\hline & \multirow[b]{2}{*}{ Usage Items } & \multicolumn{3}{|c|}{ Playing } & \multicolumn{3}{|c|}{ Livelihood Opportunity } & \multicolumn{5}{|c|}{ Recreational Use } & \multicolumn{4}{|c|}{ Utilization Diversity } \\
\hline & & $\begin{array}{l}\text { Playing in } \\
\text { the Water }\end{array}$ & $\begin{array}{l}\text { Boarding } \\
\text { the Boat }\end{array}$ & Fishing & COLL & $\begin{array}{l}\text { Capture } \\
\text { the Fish }\end{array}$ & SELL & OBSE & VTF & Walking & PHO & VCB & Average & S.D. & Max & Min \\
\hline & \multicolumn{16}{|c|}{ Degree of attachment } \\
\hline \multirow{5}{*}{$\begin{array}{c}\text { Frequency } \\
\text { of Visits }\end{array}$} & Once or twice a week & $0(0.0 \%)$ & $0(0.0 \%)$ & $0(0.0 \%)$ & $0(0.0 \%)$ & $0(0.0 \%)$ & $1(3.2 \%)$ & $1(3.2 \%)$ & $0(0.0 \%)$ & $3(9.6 \%)$ & $2(6.4 \%)$ & $3(9.6 \%)$ & 2.5 & 2.2 & 6 & 0 \\
\hline & Once or twice a month & $0(0.0 \%)$ & $0(0.0 \%)$ & $0(0.0 \%)$ & $1(3.2 \%)$ & $0(0.0 \%)$ & $0(0.0 \%)$ & $1(3.2 \%)$ & $1(3.2 \%)$ & $3(9.6 \%)$ & $2(6.4 \%)$ & $1(3.2 \%)$ & 3.7 & 3.0 & 7 & 1 \\
\hline & Once or twice a half-year & $0(0.0 \%)$ & $0(0.0 \%)$ & $0(0.0 \%)$ & $0(0.0 \%)$ & $0(0.0 \%)$ & $0(0.0 \%)$ & $1(3.2 \%)$ & $1(3.2 \%)$ & $2(6.4 \%)$ & $0(0.0 \%)$ & $4(12.9 \%)$ & 1.7 & 1.8 & 5 & 0 \\
\hline & Once a year & $0(0.0 \%)$ & $0(0.0 \%)$ & $0(0.0 \%)$ & $0(0.0 \%)$ & $0(0.0 \%)$ & $0(0.0 \%)$ & $1(3.2 \%)$ & $1(3.2 \%)$ & $1(3.2 \%)$ & $1(3.2 \%)$ & $3(9.6 \%)$ & 1.3 & 1.3 & 3 & 0 \\
\hline & Not go at all & $0(0.0 \%)$ & $0(0.0 \%)$ & $0(0.0 \%)$ & $0(0.0 \%)$ & $0(0.0 \%)$ & $0(0.0 \%)$ & $0(0.0 \%)$ & $0(0.0 \%)$ & $1(3.2 \%)$ & $0(0.0 \%)$ & $1(3.2 \%)$ & 0.6 & 0.5 & 1 & 0 \\
\hline
\end{tabular}


Table A6. Changes in attachment towards the Fukushima-gata lagoon and actual use situation of the Fukushima-gata lagoon before reclamation project $(\mathrm{n}=21)$.

\begin{tabular}{|c|c|c|c|c|c|c|c|c|c|c|c|c|c|c|c|c|}
\hline & \multirow[b]{2}{*}{ Usage Items } & \multicolumn{3}{|c|}{ Playing } & \multicolumn{3}{|c|}{ Livelihood Opportunity } & \multicolumn{5}{|c|}{ Recreational Use } & \multicolumn{4}{|c|}{ Utilization Diversity } \\
\hline & & $\begin{array}{l}\text { Playing in } \\
\text { the Water }\end{array}$ & $\begin{array}{c}\text { Boarding } \\
\text { the Boat }\end{array}$ & Fishing & COLL & $\begin{array}{l}\text { Capture } \\
\text { the Fish }\end{array}$ & SELL & OBSE & VTF & Walking & PHO & VCB & Average & S.D. & Max & Min \\
\hline & \multicolumn{16}{|c|}{ Changes in attachment } \\
\hline \multirow{3}{*}{ Landscape } & $\begin{array}{l}\text { Better than before the } \\
\text { reclamation project }\end{array}$ & $3(14.2 \%)$ & $4(19.0 \%)$ & $2(9.5 \%)$ & $5(23.8 \%)$ & $3(14.2 \%)$ & $5(23.8 \%)$ & $3(14.2 \%)$ & $2(9.5 \%)$ & $2(9.5 \%)$ & $0(0.0 \%)$ & $3(14.2 \%)$ & 5.5 & 5.7 & 13 & 0 \\
\hline & $\begin{array}{l}\text { Worse than before the } \\
\text { reclamation project }\end{array}$ & $4(19.0 \%)$ & $4(19.0 \%)$ & $3(14.2 \%)$ & $6(28.5 \%)$ & $5(23.8 \%)$ & $2(9.5 \%)$ & $3(14.2 \%)$ & $2(9.5 \%)$ & $1(4.7 \%)$ & $0(0.0 \%)$ & $1(4.7 \%)$ & 5.7 & 3.1 & 10 & 1 \\
\hline & Not change & $5(23.8 \%)$ & $4(19.0 \%)$ & $3(14.2 \%)$ & $4(19.0 \%)$ & $3(14.2 \%)$ & $2(9.5 \%)$ & $0(0.0 \%)$ & $0(0.0 \%)$ & $5(23.8 \%)$ & $0(0.0 \%)$ & $1(4.7 \%)$ & 2.1 & 2.9 & 9 & 0 \\
\hline \multirow{3}{*}{$\begin{array}{l}\text { Water } \\
\text { Transparency }\end{array}$} & $\begin{array}{l}\text { Better than before the } \\
\text { reclamation project }\end{array}$ & $5(23.8 \%)$ & $5(23.8 \%)$ & $3(14.2 \%)$ & $6(28.5 \%)$ & $4(19.0 \%)$ & $4(19.0 \%)$ & $2(9.5 \%)$ & $1(4.7 \%)$ & $2(9.5 \%)$ & $1(4.7 \%)$ & $3(14.2 \%)$ & ) 6.6 & 4.5 & 13 & 2 \\
\hline & $\begin{array}{l}\text { Worse than before the } \\
\text { reclamation project }\end{array}$ & $4(19.0 \%)$ & $4(19.0 \%)$ & $3(14.2 \%)$ & $5(23.8 \%)$ & $4(19.0 \%)$ & $3(14.2 \%)$ & $4(19.0 \%)$ & $3(14.2 \%)$ & $1(4.7 \%)$ & $0(0.0 \%)$ & $1(4.7 \%)$ & 6.7 & 3.4 & 10 & 1 \\
\hline & Not change & $4(19.0 \%)$ & $4(19.0 \%)$ & $4(19.0 \%)$ & $4(19.0 \%)$ & $3(14.2 \%)$ & $2(9.5 \%)$ & $0(0.0 \%)$ & $0(0.0 \%)$ & $1(4.7 \%)$ & $1(4.7 \%)$ & $1(4.7 \%)$ & 1.4 & 2.7 & 9 & 0 \\
\hline \multirow{3}{*}{ Safety } & $\begin{array}{l}\text { Better than before the } \\
\text { reclamation project }\end{array}$ & $5(23.8 \%)$ & $6(28.5 \%)$ & $5(23.8 \%)$ & $7(33.3 \%)$ & $5(23.8 \%)$ & $5(23.8 \%)$ & $3(14.2 \%)$ & $2(9.5 \%)$ & $1(4.7 \%)$ & $0(0.0 \%)$ & $2(9.5 \%)$ & 5.1 & 4.4 & 12 & 0 \\
\hline & $\begin{array}{l}\text { Worse than before the } \\
\text { reclamation project }\end{array}$ & $4(19.0 \%)$ & $4(19.0 \%)$ & $1(4.7 \%)$ & $5(23.8 \%)$ & $4(19.0 \%)$ & $3(14.2 \%)$ & $3(14.2 \%)$ & $2(9.5 \%)$ & $2(9.5 \%)$ & $1(4.7 \%)$ & $2(9.5 \%)$ & 6.5 & 4.3 & 13 & 1 \\
\hline & Not change & $4(19.0 \%)$ & $3(14.2 \%)$ & $4(19.0 \%)$ & $3(14.2 \%)$ & $2(9.5 \%)$ & $1(4.7 \%)$ & $0(0.0 \%)$ & $0(0.0 \%)$ & $1(4.7 \%)$ & $1(4.7 \%)$ & $1(4.7 \%)$ & 1.5 & 2.7 & 9 & 0 \\
\hline
\end{tabular}

Table A7. Changes in attachment towards the Fukushima-gata lagoon and actual use situation of the Fukushima-gata lagoon after reclamation project $(\mathrm{n}=21)$.

\begin{tabular}{|c|c|c|c|c|c|c|c|c|c|c|c|c|c|c|c|c|}
\hline & \multirow[b]{2}{*}{ Usage Items } & \multicolumn{3}{|c|}{ Playing } & \multicolumn{3}{|c|}{ Livelihood Opportunity } & \multicolumn{5}{|c|}{ Recreational Use } & \multicolumn{4}{|c|}{ Utilization Diversity } \\
\hline & & $\begin{array}{l}\text { Playing in } \\
\text { the Water }\end{array}$ & $\begin{array}{c}\text { Boarding } \\
\text { the Boat }\end{array}$ & Fishing & COLL & $\begin{array}{l}\text { Capture } \\
\text { the Fish }\end{array}$ & SELL & OBSE & VTF & Walking & PHO & VCB & Average & S.D. & $\operatorname{Max}$ & Min \\
\hline & \multicolumn{16}{|c|}{ Changes in Attachment } \\
\hline \multirow{3}{*}{ Landscape } & $\begin{array}{l}\text { Better than before the } \\
\text { reclamation project }\end{array}$ & $0(0.0 \%)$ & $0(0.0 \%)$ & $0(0.0 \%)$ & $1(4.7 \%)$ & $0(0.0 \%)$ & $1(4.7 \%)$ & $1(4.7 \%)$ & $2(9.5 \%)$ & $3(14.2 \%)$ & $2(9.5 \%)$ & $4(19.0 \%)$ & 2.7 & 2.7 & 7 & 0 \\
\hline & $\begin{array}{l}\text { Worse than before the } \\
\text { reclamation project }\end{array}$ & $0(0.0 \%)$ & $0(0.0 \%)$ & $1(4.7 \%)$ & $1(4.7 \%)$ & $1(4.7 \%)$ & $0(0.0 \%)$ & $3(14.2 \%)$ & $1(4.7 \%)$ & $3(14.2 \%)$ & $1(4.7 \%)$ & $3(14.2 \%)$ & ) 3.6 & 2.5 & 6 & 0 \\
\hline & Not change & $0(0.0 \%)$ & $0(0.0 \%)$ & $0(0.0 \%)$ & $0(0.0 \%)$ & $0(0.0 \%)$ & $0(0.0 \%)$ & $1(4.7 \%)$ & $0(0.0 \%)$ & $4(19.0 \%)$ & $2(9.5 \%)$ & $5(23.8 \%)$ & ) 1.0 & 0.9 & 3 & 0 \\
\hline \multirow{3}{*}{$\begin{array}{l}\text { Water } \\
\text { Transparency }\end{array}$} & $\begin{array}{l}\text { Better than before the } \\
\text { reclamation project }\end{array}$ & $0(0.0 \%)$ & $0(0.0 \%)$ & $0(0.0 \%)$ & $0(0.0 \%)$ & $0(0.0 \%)$ & $1(4.7 \%)$ & $1(4.7 \%)$ & $0(0.0 \%)$ & $3(14.2 \%)$ & $2(9.5 \%)$ & $2(9.5 \%)$ & 2.0 & 2.1 & 6 & 0 \\
\hline & $\begin{array}{l}\text { Worse than before the } \\
\text { reclamation project }\end{array}$ & $0(0.0 \%)$ & $0(0.0 \%)$ & $1(4.7 \%)$ & $1(4.7 \%)$ & $1(4.7 \%)$ & $0(0.0 \%)$ & $3(14.2 \%)$ & $2(9.5 \%)$ & $3(14.2 \%)$ & $1(4.7 \%)$ & $2(9.5 \%)$ & 3.8 & 2.8 & 7 & 0 \\
\hline & Not change & $0(0.0 \%)$ & $0(0.0 \%)$ & $0(0.0 \%)$ & $1(4.7 \%)$ & $0(0.0 \%)$ & $0(0.0 \%)$ & $1(4.7 \%)$ & $1(4.7 \%)$ & $4(19.0 \%)$ & $2(9.5 \%)$ & $5(23.8 \%)$ & ) 1.1 & 1.1 & 3 & 0 \\
\hline \multirow{3}{*}{ Safety } & $\begin{array}{l}\text { Better than before the } \\
\text { reclamation project }\end{array}$ & $0(0.0 \%)$ & $0(0.0 \%)$ & $0(0.0 \%)$ & $1(4.7 \%)$ & $0(0.0 \%)$ & $0(0.0 \%)$ & $1(4.7 \%)$ & $2(9.5 \%)$ & $3(14.2 \%)$ & $1(4.7 \%)$ & $5(23.8 \%)$ & ) 1.9 & 2.4 & 7 & 0 \\
\hline & $\begin{array}{l}\text { Worse than before the } \\
\text { reclamation project }\end{array}$ & $0(0.0 \%)$ & $0(0.0 \%)$ & $1(4.7 \%)$ & $1(4.7 \%)$ & $1(4.7 \%)$ & $1(4.7 \%)$ & $3(14.2 \%)$ & $1(4.7 \%)$ & $3(14.2 \%)$ & $2(9.5 \%)$ & $2(9.5 \%)$ & 4.0 & 2.3 & 6 & 0 \\
\hline & Not change & $0(0.0 \%)$ & $0(0.0 \%)$ & $0(0.0 \%)$ & $0(0.0 \%)$ & $0(0.0 \%)$ & $0(0.0 \%)$ & $1(4.7 \%)$ & $0(0.0 \%)$ & $4(19.0 \%)$ & $2(9.5 \%)$ & $5(23.8 \%)$ & ) 1.1 & 1.0 & 3 & 0 \\
\hline
\end{tabular}




\section{References}

1. Watanabe, Y.; Yokohari, M. Characteristics of "Bread-and-Butter" Landscapes Recognized by Rural Residents as Important Components of Regional Identity Viewed from Behaviors and Distance. J. Jpn. Inst. Landsc. Arch. 2010, 73, 643-646. [CrossRef]

2. Graham, B.; Barbara, B.; Douglas, P. New housing as neighborhood revitalization: Place attachment and confidence among residents. Environ. Behav. 2004, 36, 749-775.

3. Watanabe, Y. Keikan Kenkyu Ni Okeru Toranzakusyon: Nouson Chiiki Ni Oite Chiikiaidentexitexi Tosite Ninshiki Sareru Seikatsukei (The concept of transaction in landscape research: Ordinary landscapes recognized as local identity in rural areas). Mera J. 2010, 13, 79-88.

4. The Niigata City Lagoon Environment Research Institute for Environmental Studies. Fukushimagata (Fukushima-Gata Lagoon). Available online: http://www.niigata-satokata.com/learn/fukushimagata/ (accessed on 6 January 2019).

5. The Niigata City Lagoon Environment Research Institute for Environmental Studies. Kata no naritachi (The Origins of Fukushima-Gata Lagoon). Available online: http://www.niigata-satokata.com/learn/naritachi/ (accessed on 6 January 2019).

6. Geospatial Information Authority of Japan. Kiban Chizu Jouhou Download Service (Basic Map Information Download Service). Available online: https://fgd.gsi.go.jp/download/menu.php (accessed on 9 January 2019).

7. Sweers, W.; Horn, S.; Grenzdörffer, G.; Müller, J. Regulation of reed (Phragmites australis) by water buffalo grazing: Use in coastal conservation. Mires Peat 2013, 13, 1-10.

8. David, M.; Cesar, P.; Francisco, A.; Mercedes, G.; Alvaro, C. Creating wetlands for the improvement of water quality and landscape restoration in semi-arid zones degraded by intensive agricultural use. Ecol. Eng. 2007, 30, 103-111.

9. Garcia-Ayllon, S. The Integrated Territorial Investment (ITI) of the Mar Menor as a model for the future in the comprehensive management of enclosed coastal seas. Ocean Coast. Manag. 2018, 166, 82-97. [CrossRef]

10. Levers, L.R.; Skaggs, T.H.; Schwabe, K.A. Buying water for the environment: A hydro-economic analysis of Salton Sea inflows. Agric. Water Manag. 2019, 213, 554-567. [CrossRef]

11. Velasco, A.; Perez-Ruzafa, A.; Martinez-Paz, J.M.; Marcos, C. Ecosystem services and main environmental risks in a coastal lagoon (Mar Menor, Murcia, SE Spain): The public perception. J. Nat. Conserv. 2018, 43, 180-189. [CrossRef]

12. Garcia-Ayllon, S. Long-Term GIS Analysis of Seaside Impacts Associated to Infrastructures and Urbanization and Spatial Correlation with Coastal Vulnerability in a Mediterranean Area. Water 2018, 10, 1642. [CrossRef]

13. Hidalgo, M.C.; Hernandez, B. Place Attachment: Conceptual and Empirical Questions. J. Environ. Psychol. 2001, 21, 273-281. [CrossRef]

14. Jennings, B. Seasonal Outlook: An Examination of How the Foundations of Attachment to Community Differ between Seasonal and Year-Round Residents in High Amenity Areas. Ph.D. Thesis, Utah State University, Logan, UT, USA, 2009.

15. Lewicka, M. Ways to make people active: The role of place attachment, cultural capital, and neighborhood ties. J. Environ. Psychol. 2005, 25, 381-395. [CrossRef]

16. Halpenny, E. Environmental Behaviour, Place Attachment and Park Visitation: A Case Study of Visitors to Point Pelee National Park. Ph.D. Thesis, University of Waterloo, Waterloo, ON, Canada, 2006.

17. Brehm, J.; Eisenhauer, B.; Krannich, R. Dimensions of Community Attachment and Their Relationship to Well-Being in the Amenity-Rich Rural West. Rural Sociol. 2009, 69, 405-429. [CrossRef]

18. Junro, T. Community Sentiment Ni Kansuru Ichi Kousatsu: Chiiki He No Aicyaku Ishiki Wo Cyuushin Ni (A Study on Community Sentiment: Focusing on Attitudes of Attachment to Regions). Shukutoku Univ. Bull. 1982, 16, 45-63.

19. Hikichi, H.; Aoki, T. Chiiki Ni Taisuru Aicyaku Keisei No Shinri Katei No Kentou (A study of psychological process of attachment formation to the region). Landsc. Des. Comm. JSCE 2005, 1, 232-235.

20. Matsumoto, N.; Tatebe, K.; Hanai, M. Mental Distances and Directions to Places IN Children's Living Environments: A study on the mental scenery of children Part 2. J. Arch. Plan. 2004, 575, 69-76. [CrossRef]

21. Ryan, R. Exploring the Effects of Environmental Experience on Attachment to Urban Natural Areas. Environ. Behav. 2005, 37, 3-42. [CrossRef] 
22. Moore, R.; Scott, D. Place Attachment and Context: Comparing a park and a trial within. For. Sci. 2003, 49, 877-884.

23. Cuba, L.; Hummon, D. A Place to Callhome: Identification with Dwelling, Community, and Region. Sociol. Q. 1993, 34, 111-131. [CrossRef]

24. Mesch, G.; Talmud, I. Internet Connectivity, Community Participation, and Place Attachment: A Longitudinal Study. Am. Behav. Sci. 2010, 53, 1095-1110. [CrossRef]

25. Dallago, L.; Perkins, D.; Santinello, M.; Boyce, W.; Molcho, M. Adolescent Place Attachment, Social Capital, and Perceived Safety: A Comparison of 13 Countries. Am. J. Community Psychol. 2009, 44, 148-160. [CrossRef]

26. Brown, B.; Perkins, D.; Brown, G. Place attachment in a revitalizing neighborhood: Individual and block levels of analysis. J. Environ. Psychol. 2003, 23, 259-271. [CrossRef]

27. Hagiwara, G.; Fujii, S. Koutsu Koudou Ga Chiiki Aityaku Ni Ataeru Eikyou Ni Kansuru Bunseki (The psychological effects of travel behavior on place attachment). Proc. Infrastruct. Plan. 2005, 32, 285.

28. Suzuki, H.; Fujii, S. Study on Effects of Consumer Behavior on Place Attachment. Doboku Gakkai Ronbunshuu D 2008, 64, 190-200. [CrossRef]

29. Ryan, L.; Kaplan, R.; Grese, R. Predicting Volunteer Commitment in Environmental Stewardship Programmes. J. Environ. Plan. Manag. 2001, 44,629-648. [CrossRef]

30. Isa, M. Place attachment to waterfront revitalisation development: Case study of Lumut and Kuching, Malaysia. Ph.D. Thesis, University of Malaya, Kuala Lumpur, Malaysia, 2017.

31. Eisenhauer, B.; Krannich, R.; Blahna, D. Attachments to Special Places on Public Lands: An Analysis of Activities, Reason for Attachments, and Community Connections. Soc. Nat. Resour. 2000, 13, 421-441.

32. White, D.; Virden, R.; Riper, C. Effects of Place Identity, Place Dependence, and Experience-Use History on Perceptions of Recreational use Impacts in a Natural Setting. Environ. Manag. 2008, 42, 647-657. [CrossRef] [PubMed]

33. Helen, A.; Neil, A. The contribution of ecosystem services to place utility as a determinant of migration decision-making. Environ. Res. Lett. 2013, 8, 15006.

34. Greg, B.; Christopher, R.; Jonathan, C. Mapping and measuring place attachment. Appl. Geogr. 2015, 57, 42-53.

35. Walker, A.; Ryan, R. Place attachment and landscape preservation in rural New England: A Maine case study. Landsc. Urban Plan. 2008, 86, 141-152. [CrossRef]

36. Ramkissoon, H.; Weiler, B.; Smith, L. Place attachment and pro-environmental behaviour in national parksthe development of a conceptual framework. J. Sustain. Tour. 2012, 20, 257-276. [CrossRef]

37. Mowen, A.; Graefe, A.; Virden, R. A typology of place attachment and activity involvement. In Proceedings of the 1997 Northeastern Recreation Research Symposium, Bolton Landing, NY, USA, 6-9 April 1997; Gen. Tech. Rep. NE-241. Vogelsong, Hans G., Ed.; U.S. Department of Agriculture, Forest Service, Northeastern Forest Experiment Station: Radnor, PA, USA; pp. 82-92.

38. Scannell, L.; Gifford, R. The relations between natural and civic place attachment and pro-environmental behavior. J. Environ. Psychol. 2010, 30, 289-297. [CrossRef]

39. Yamanouchi, T.; Akasaka, M.; Kadono, Y.; Takamura, N. Prioritizing Japanese lakes for aquatic macrophyte preservation: The use of different systems. Jpn. J. Preserv. Ecol. 2016, 21, 135-146.

40. Kubota, A.; Ozaki, M.; Hasegawa, S.; Okada, T. Niigata Heiya Ni Okeru Jiban Hendou No Cyousa Kekka To Kaiseki (Survey results and analysis of ground changes in the Niigata plain). J. Agric. Eng. Soc. Jpn. 1982, 50, 569-576.

41. Shimada, T. Movements of Bean Geese relative to snowfall within the wintering grounds. Bird Res. 2010, 6, 7-11.

42. Tanabe, T.; Okuma, T.; Nakagawa, T. A Study on the Flood Control which Allows the Water to Overflow on the Right Bank District of Aganogawa-River; Contemporary Evaluations on Roles of Shirakawa-Weir and liaguro-Weir on Annogawa-River Basin. J. Hist. Stud. Civ. Eng. 2000, 20, 129-140. [CrossRef]

43. Tamura, M.; Araki, N. Fukushima-gata Shizenseitaien Seibi Keikaku (Fukushima-gata Lagoon Ecological Park Planning). J. Jpn. Soc. Civ. Eng. 1992, 77, 18-21.

44. The Niigata City Lagoon Environment Research Institute for Environmental Studies. Heisei 28 Nendo Niigatashi Kata Kenkyujo Kenkyu Seika Houkoku (Niigata City Lagoon Environment Research Institute Research Results Report, 2016). Available online: http://www.niigata-satokata.com/cat_dat/dat00001--3/ (accessed on 6 January 2019). 
45. The Niigata City Lagoon Environment Research Institute for Environmental Studies. Minna No Katagaku -Echigo Heiya Ni Okeru Aratana Chiikigaku-(Everyone's Lagoon Studies-New Regional Studies in the Echigo Plain-); ASTAGE Co., Ltd.: Niigata, Japan, 2018.

46. Kim, J.; Fujimoto, N.; Mitsubashi, N. On the Effect of Workshop toward Making up Local Identity of a Mountainous Settlement; A Case Study in Kuriyama Village, Tochigi Pref. J. City Plan. Inst. Jpn. 1996, 31, 151-156.

47. Setsuko, M.; Furukawa, N. Chiiki Identity No Keisei Ni Hatasu ke-buru terebi No Yakuwari Kyu Kanzaki Machi Community Channel Wo Zirei To Shite (The Function of Cable Television in the Formation of Community Identity: A Case Study in Kanzaki Community Channel). Res. Rep. Univ. Hyogosch. Hum. Sci. Environ. 2007, 9, 83-91.

48. Watanabe, Y.; Yokohari, M.; Ochiai, M. Rural Landscapes with Greenhouses as a Regional Identity. J. Jpn. Inst. Landsc. Arch. 2008, 71,747-775. [CrossRef]

49. Niigata City. Shisei Yoron Chousa (Municipal Poll). Available online: http://www.city.niigata.lg.jp/shisei/ kocho/yoron/45yorontyousa.files/45hokokusyo.pdf (accessed on 6 January 2019).

50. Ministry of the Environment Government of Japan. Mizu Shirube Mizu Kankyou Kenzen Sei Shiyou. Water Environ. Soundness Index. Available online: http://www.env-u-tokyo.jp/wesi/ (accessed on 14 June 2019).

51. The Asahi Shimbun. Fukushimagata Shizenhakai Susumu (Natural destruction of Fukushima-gata lagoon progresses). The Asahi Shimbun, 20 June 1989.

52. Saito, K. Historico-Geographical Investigation on the Fukushima-gata lagoon, Niigata Prefecture. Jpn. J. Hum. Geogr. 1961, 13, 203-220. [CrossRef]

(C) 2019 by the authors. Licensee MDPI, Basel, Switzerland. This article is an open access article distributed under the terms and conditions of the Creative Commons Attribution (CC BY) license (http://creativecommons.org/licenses/by/4.0/). 